\title{
Litter inputs and phosphatase activity control the temporal variability of organic phosphorus in a tropical forest soil in the Central Amazon
}

Karst J. Schaap ( $\sim$ karstsch@gmail.com )

Soil Chemistry, Wageningen University, P.O. Box 47, 6700AA Wageningen, The Netherlands; Coordination of Environmental Dynamics (CODAM), National Institute of Amazonian Research (INPA), Manaus, Brazil https://orcid.org/0000-0003-1627-9029

\section{Lucia Fuchslueger}

University of Vienna, Althanstrasse https://orcid.org/0000-0002-9615-4439

\section{Marcel R. Hoosbeek}

Wageningen University \& Research https://orcid.org/0000-0003-0617-0089

\section{Florian Hofhansl}

International Institute for Applied Systems Analysis (IIASA) https://orcid.org/0000-0003-0073-0946

\section{Nathielly Pires Martins}

Coordination of Environmental Dynamics (CODAM), National Institute of Amazonian Research (INPA), Manaus, Brazil https://orcid.org/0000-0002-2501-747X

\section{Oscar J. Valverde-Barrantes}

Florida International University, Miami https://orcid.org/0000-0002-7327-7647

lain P. Hartley

University of Exeter https://orcid.org/0000-0002-9183-6617

\section{Laynara F. Lugli}

Coordination of Environmental Dynamics (CODAM), National Institute of Amazonian Research (INPA), Manaus, Brazil https://orcid.org/0000-0001-8404-4841

\section{Carlos Alberto Quesada}

Coordination of Environmental Dynamics (CODAM), National Institute of Amazonian Research (INPA), Manaus, Brazil

\section{Research Article}

Keywords: Amazon, P fractionation, Lowland tropical forest, Phosphatase activity, Phosphorus cycle, Leaf litter

Posted Date: June 8th, 2021

DOI: https://doi.org/10.21203/rs.3.rs-548371/v1 
License: (c) (i) This work is licensed under a Creative Commons Attribution 4.0 International License. Read Full License 


\title{
Litter inputs and phosphatase activity control the temporal variability of organic phosphorus in a tropical forest soil in the Central Amazon
}

\author{
Karst J. Schaap • Lucia Fuchslueger . \\ Marcel R. Hoosbeek • Florian Hofhansl . \\ Nathielly Pires Martins . Oscar J. \\ Valverde-Barrantes • Iain P. Hartley . \\ Laynara F. Lugli • Carlos Alberto Quesada
}

Received: date / Accepted: date

\begin{abstract}
Purpose. The tropical phosphorus-cycle and its impacts on phosphorus (P) availability are a major uncertainty in projections of forest productivity. In highly weathered soils with low $\mathrm{P}$ concentrations, plant and microbial communities depend on biological and physical processes to acquire P. We explored the seasonality and relative importance of drivers controlling the fluctuation of common $\mathrm{P}$ pools via processes such as litter production and decomposition, and soil phosphatase activity.

Methods. We analyzed variation of standard tropical soil phosphorus pools over one year. In addition, we measured litterfall, its decomposition rates and soil extracellular phosphatase enzyme activity and tested their relation to the fluctuations in P-fractions.

Results. Our results show clear patterns of seasonal variability of soil P fractions during the year. We found that modeled $\mathrm{P}$ released during litter decomposition is
\end{abstract}

Karst J. Schaap* . Marcel R. Hoosbeek

Soil Chemistry, Wageningen University, P.O. Box 47, 6700AA Wageningen, The Netherlands * corresponding author, E-mail: karstsch@gmail.com

Karst J. Schaap · Nathielly Pires Martins · Laynara F. Lugli · Carlos Alberto Quesada Coordination of Environmental Dynamics (CODAM), National Institute of Amazonian Research (INPA), Manaus, Brazil

Lucia Fuchslueger

Centre of Microbiology and Environmental Systems Science, Div. Terrestrial Ecosystem Research, University of Vienna, Althanstrasse 14, 1090 Vienna, Austria

Florian Hofhansl

International Institute for Applied Systems Analysis (IIASA), Schlossplatz 1, A-2361 Laxenburg, Austria

Oscar J. Valverde-Barrantes

Institute of Environment, Department of Biological Sciences, Florida International University, Miami, FL 33199 USA

Iain P. Hartley

Geography. College of Life and Environmental Studies, University of Exeter, Exeter, EX4 4RJ, United Kingdom 
positively related to change in organic $\mathrm{P}$ fractions, while net change in organic $\mathrm{P}$ fractions was negatively related to phosphatase activities in the top $5 \mathrm{~cm}$.

Conclusion. We conclude that input of organic $\mathrm{P}$ forms by litter decomposition and organically produced phosphatases are the two main factors controlling seasonal soil $\mathrm{P}$ fluctuation, and therefore the $\mathrm{P}$ economy in $\mathrm{P}$ impoverished soils. Organic soil $\mathrm{P}$ follows a clear seasonal pattern, indicating tight cycling of the nutrient, while reinforcing the importance of studying soil $\mathrm{P}$ as an integrated dynamic system in a tropical forest context.

Keywords Amazon · P fractionation - Lowland tropical forest · Phosphatase activity $\cdot$ Phosphorus cycle $\cdot$ Leaf litter

\section{Introduction}

The Amazon Basin contains about one third of the world's remaining tropical forests (Mayaux et al., 2005), playing an important role in the global carbon (C) cycle. Currently, the Amazon rainforest absorbs $\sim 0.5 \mathrm{GT} \mathrm{C} \mathrm{yr}^{-1}$ (Pan et al., 2011), but recent evidence suggests that it is losing its capability to increase productivity, potentially induced by rising temperatures and greater drought frequency or by reaching a new state of equilibria adapting to changing climate conditions (Brienen et al., 2015; Hubau et al., 2020). One factor that could enhance the resilience of the forest to climate change is the $\mathrm{CO}_{2}$-fertilization effect, where rising atmospheric $\mathrm{CO}_{2}$ concentrations could boost forest productivity (Zhu et al., 2016). However, the magnitude of this effect may depend on the availability of factors such light, water, and nutrients (Du et al., 2020). While in natural forest ecosystems in temperate areas nitrogen $(\mathrm{N})$ is the most limiting nutrient for plant productivity (Oren et al., 2001; Vitousek, 1982), tropical forest ecosystems are generally considered to be constrained by P availability (Hofhansl et al., 2020; Townsend et al., 2011; Vitousek, 1984) with feedbacks to the nitrogen cycle (Nasto et al., 2014; Quesada et al., 2010). Across the Amazonian basin, soil phosphorus (P) has been shown to be positively related to forest productivity (Aragão et al., 2009; Quesada et al., 2012) and the inclusion of $P$ cycles in regional dynamic vegetation models suggest $\mathrm{P}$ limitation will be important in controlling forest productivity and the responses of tropical biomes to global change (Fleischer et al., 2019; Terrer et al., 2019). However, many key processes controlling $\mathrm{P}$ availability in tropical forests remain poorly understood.

Approximately $60 \%$ of Amazonian forests grow on geologically old and highly weathered soils, typically Ferralsols or Acrisols, with low nutrient concentrations (Quesada et al., 2011). This is in line with the assumptions of the P pedogenetic model conceptualized by Walker and Syers (1976), where rock derived (mineral) $\mathrm{P}$ ends up in the organic, occluded, and non-occluded (i.e., more available) pools at the start of pedogenesis, but after the parent material as a $\mathrm{P}$ source depletes, $\mathrm{P}$ availability declines sharply. Total $\mathrm{P}$ declines during this soil aging process, due to losses - like leaching - from the system. Eventually most soil $\mathrm{P}$ will be either occluded or in organic pools - a phenomenon dramatically described as a "terminal steady state" (Walker and Syers, 1976). In older, more weathered soils, a larger proportion of $\mathrm{P}$ can be found in organic forms and highlights the increased importance of biological activity. 
While $\mathrm{P}$ is an essential element for plants and microbes, the directly plantavailable fraction is usually a relatively small pool compared to the total $\mathrm{P}$ concentration (Tiessen, 2008), and the chemical availability of $\mathrm{P}$ is dictated by the solubility of ortho-P in a soil, which is mainly defined by sorption-desorption kinetics (Hinsinger, 2001). A common method to characterize $\mathrm{P}$ accessibility in soils was developed by Hedley et al. (1982), to identify a series of P fractions based on their solubility that represent different levels of bioavailability for inorganic $\left(\mathrm{P}_{i}\right)$ and organic $\mathrm{P}$ fractions $\left(\mathrm{P}_{o}\right)$ (Fig. 1, Tiessen and Moir, 1993). The $\mathrm{P}_{i}$ fractions include water-soluble $\mathrm{P}$, which should be directly available to plants, but also $\mathrm{P}$ bound to aluminum $(\mathrm{Al})$ and iron $(\mathrm{Fe})$, up to $\mathrm{P}$ bound to calcium $(\mathrm{Ca})$ and is therefore usually poorly accessible to plants (Cross and Schlesinger, 1995). In soils with low or no $\mathrm{Ca}$, this last fraction is likely to consist of recalcitrant organic matter or otherwise occluded $\mathrm{P}$. In comparison with other anions, $\mathrm{P}_{i}$ has a relatively low mobility in soil (Johnson and Cole, 1980). High kaolinite clay contents and high amounts of $\mathrm{Al}$ and $\mathrm{Fe}$ oxides amplified by low soil $\mathrm{pH}$, common for tropical soils, facilitate sorption of $\mathrm{P}_{i}$, further reducing its mobility (McGechan and Lewis, 2002). The organic $P$ fractions $\left(P_{o}\right)$ are more difficult to interpret than the $P_{i}$ fractions. They are on the same solubility continuum from water to Ca-bound, being directly derived from plant or microbial sources or from the soil organic matter (SOM). Organic P forms are more complex (e.g. phospholipids, DNA, phosphate monoesters, glucophosphates, phytic acids) and have the potential to be an important contributor to P-bioavailability through chemical and biochemical plant acquisition strategies (Darch et al., 2016).

Plants have evolved various mechanisms to maintain a bioavailable pool of P; these mechanisms include an increased presence of root mats in the forest floor, fine roots, association with mycorrhizae for $\mathrm{P}$ uptake, root exudation of enzymes for mineralization of organic compounds, or exudation to change sorption or microbial activity through the "priming" effect (Buendía et al., 2014; Herrera et al., 1978; Hinsinger, 2001; Lugli et al., 2020; Stark and Jordan, 1978; Steidinger et al., 2015). With declining plant available $\mathrm{P}$ and a relatively larger organic $\mathrm{P}$ pool (Turner et al., 2007), plant strategies for efficient recycling and uptake are increasingly relevant (Roberts et al., 2015). Plants might apply different strategies to compete for P (Nasto et al., 2017; Raven et al., 2018; Steidinger et al., 2015). From a plant perspective, those strategies can be categorized as either foraging or mining strategies (Richardson et al., 2011). Foraging strategies serve to explore more soil, while mining strategies are used to access forms of $\mathrm{P}$ by chemical alteration in the soil, for example through the excretion of enzymes (Hinsinger, 2001; Lloyd et al., 2001). However, root phosphatase has been shown to only account for a small fraction of total soil phosphatase activity, underlining the importance of microbial processes in the rhizosphere for P dynamics (Cabugao et al., 2021). While organic bound $\mathrm{P}$ is not directly available, phosphatases catalyzing the degradation of organic molecules might rapidly change the available pool of $\mathrm{P}$ in the tropics (Wood et al., 2016) and thus can be used as a general proxy for demand of $\mathrm{P}$ (Vance et al., 2003).

With declining delivery rate of $\mathrm{P}_{i}$ from mineral sources, the recycling of $\mathrm{P}$ and the dynamics in the organic $\mathrm{P}$ pools become increasingly important. One of the largest fluxes of organic matter in tropical forests is leaf litterfall, with fluctuations and annual phenological cycles driven by changes in water availability and solar irradiation (Wu et al., 2016). Seasonality of rainfall is an important deter- 
minant of litterfall, though fluctuations may vary per region (Chave et al., 2010). Litterfall and its decomposition constitutes an important flux of organic material (and thus nutrients like P) to the soil (Luizão, 1989), to maintain nutrient stocks and mineralize $\mathrm{P}$ bound in organic molecules and ultimately to plant uptake facilitating biomass production. However, there is an offset between litterfall peak production in the drier season and the mineralization of nutrients in Central Amazonia (Luizão and Schubart, 1987). Typically, microorganisms decompose litter, showing a quick initial release of soluble nutrients at the onset of initial decomposition, which gradually reduces over time (i.e. 30-60 days), which control the rate nutrients enter the mineral soil. Moreover, seasonal fluctuations in precipitation also affect the decomposition dynamics, not only through the release of soluble compounds, but also by affecting soil moisture and the activity of the microbial community (Krishna and Mohan, 2017). If nutrient pulses aboveground are synchronized with the nutrient availabilities and plant strategies belowground, this might have implications for our understanding of the dynamic nutritional system that underlies the functioning of the forest.

In this study, we aimed to evaluate the temporal dynamics of soil Hedley $\mathrm{P}$ fractions in a Central Amazonian forest with low soil P content. We suspected that different soil $\mathrm{P}$ fractions are not static but vary over time. We expected fluctuations to be most pronounced in the top $5 \mathrm{~cm}$ where the biological activity is highest, while in the soil below $(5-15 \mathrm{~cm})$ we would expect the same pattern but with a smaller amplitude. Moreover, we expected that hypothesized variation is driven by fluctuating inputs (litterfall), subsequential decomposition derived organic and inorganic $\mathrm{P}$ inputs to the soil, exchange between soil $\mathrm{P}$ fractions (catalyzed by phosphatase activities, among others), and outputs (i.e. plant uptake). We aimed to identify the relative importance of drivers controlling the fluctuation of different $\mathrm{P}$ pools, such as litterfall inputs, litter decomposition and phosphatase activity from either plant roots or microbes to degrade $\mathrm{P}_{o}$ compounds. We hypothesized that $\mathrm{P}_{o}$ is fluctuating driven by (1) litterfall inputs, and on the other hand (2) degradation by phosphatase activity, such that (3) both litterfall and enzyme activities follow a seasonal pattern, which reflects differences in biological activity and soil P-release, visible in $\mathrm{P}_{i}$ fractions if not taken up by plants.

\section{Methods}

Site description

The study was carried out at the AmazonFACE experimental site $\left(2^{\circ} 35^{\prime} 40^{\prime \prime} \mathrm{S}\right.$, $60^{\circ} 12^{\prime} 29^{\prime \prime} \mathrm{W}$ ) in Central Amazonia (more info on https://amazonface.inpa.gov.br/), approximately $70 \mathrm{~km}$ north of Manaus, Brazil, in the "Cuieiras" experimental reserve (Estação Experimental de Silvicultura Tropical - EEST, see also Pereira et al., 2019). Characteristic for the area are old-growth tropical forests locally known as "Terra Firme" forests, situated on plateaus with nutrient poor and clayrich soils (>70\% clay) classified as Geric Ferralsols (Quesada et al., 2010). Average annual rainfall is about $2,400 \mathrm{~mm}$, with drier period from June to October, while the average temperature fluctuates from $25.8^{\circ} \mathrm{C}$ in April to $27.9^{\circ} \mathrm{C}$ in September (Araújo et al., 2002). 
Soil sample collection

Soils were sampled from 18 locations (min. distance $10 \mathrm{~m}$ ) along a transect in February, May, August, and November 2016, using a custom-made steel soil corer $(\varnothing 10 \mathrm{~cm})$. Soils were sampled at $0-5 \mathrm{~cm}$ and $5-15 \mathrm{~cm}$ depth and transported to the lab for sieving $(2 \mathrm{~mm})$, root and detritus removal and further processing. Soil aliquots were stored after weighing and oven drying $\left(48 \mathrm{~h}\right.$ at $\left.65^{\circ} \mathrm{C}\right)$ until further analysis, while microbial biomass and enzyme activity measurements were performed in fresh soil within 3 days of sampling. The moisture contents of the fresh soil were calculated from the weight differences before and after drying to express all soil properties on a dry soil basis.

\section{Soil P-fractionation}

Phosphorus fractions were determined in oven dried soils, with an adaptation of a sequential extraction method developed by Hedley et al. (1982; described by Tiessen and Moir 1993; adapted by Quesada et al. 2010). The extractant sequence was an anion exchange membrane (resin strip) in water, $0.5 \mathrm{M} \mathrm{NaHCO}_{3}$ (bicarbonate fraction, $\mathrm{pH} 8.5$ ), $0.1 \mathrm{M} \mathrm{NaOH}$ (hydroxide fraction) and $1 \mathrm{M} \mathrm{HCl}$ (hydrogen chloride fraction, Fig. 1), each of them shaking for 16 hours. All extracts were analyzed for inorganic $\mathrm{P}_{i}$. In addition, the $\mathrm{NaHCO}_{3}$ and $\mathrm{NaOH}$ extracts were digested with a sulfuric acid solution $\left(\mathrm{N}_{2} \mathrm{SO}_{4}, 0.9 M\right)$ and analyzed for total $\mathrm{P}$, which allowed the calculation of their respective organic $\left(\mathrm{P}_{o}\right)$ fraction. As an adaption to the Hedley et al./Tiessen and Moir (1993) method, the concentrated $\mathrm{HCl}-$ extraction step and digestion of the soil residue were not followed. Instead, another soil subsample was analyzed for total $\mathrm{P}$ by digestion with a concentrated sulfuric acid solution $\left(\mathrm{N}_{2} \mathrm{SO}_{4}, 18 M\right.$ ), followed by $\mathrm{H}_{2} \mathrm{O}_{2}$ (Quesada et al., 2010). All seven extracts were analyzed for $\mathrm{PO}_{4}$ concentrations photometrically $(712 \mathrm{~nm})$ using the Murphy-Riley method and are given in $\mu \mathrm{g} \mathrm{g}^{-1}$ dry soil (Murphy and Riley, 1962). Those fractions include four inorganic $\left(\mathrm{P}_{i}\right)$ fractions (in order of decreasing availability) the resin fraction, the bicarbonate fraction the hydroxide fraction, and the hydrogen chloride fraction, along with two organic bicarbonate and hydroxide extractable fractions $\left(\mathrm{P}_{o}\right)$. The residual $\mathrm{P}$ fraction was obtained from subtracting the sum of the extractable inorganic and organic P fractions from the total P (Fig. 1).

\section{Litterfall and P-input}

Litterfall was collected biweekly at the AmazonFACE plots starting in August 2015. Litter traps $(0.5 \times 0.5 \mathrm{~m})$ were installed $1 \mathrm{~m}$ above the ground. The total litter was dried, separated into leaf litter and other litter fractions, weighed, and analyzed for total P (for total P subsamples were digested with nitric-perchloric acid and concentrations determined with the Murphy-Riley method as described above) and the results were scaled up to $\mathrm{g} \mathrm{m}^{-2}$, with the standard error showing the differences between individual litter traps. We aimed to estimate $\mathrm{P}$ release from litter over time accounting for a potential delay (time lag) between leaf litterfall, its decomposition, and subsequent $\mathrm{P}$ release into soil. To estimate $\mathrm{P}$ release from 
leaf litter over time, we used data from a litter decomposition experiment with this litter at the same study site following an exponential decline as Eq. (1) (adapted from Olson, 1963), with $f$ as the mass fraction of remaining $\mathrm{P}$ in leaf litter:

$$
f(x)=e^{-b x}
$$

with $b=0.00178$ as decomposition constant $\left(\mathrm{R}^{2}=0.82\right.$, data from Martins et al., 2021) for the available 188 days of the decomposition data. To estimate $\mathrm{P}$ loss from litter from a certain litter subsample on a given day, the differential of Eq. 1, presented here as Eq. (2):

$$
f^{\prime}(x)=-b \times e^{-b x}
$$

was used. We combined this formula to litterfall data inputs (i.e. leaf litter per day for each sampling interval) to account for seasonal variation in inputs, and summed the litter P-loss from litterfall (up to an arbitrarily chosen thousand days prior) to get an estimation of the litter P-input to the soil (litter P-loss) on a given day from the following Eq. (3):

$$
-\sum_{t=0}^{1000} r \times c_{t=0}\left(-b \times e^{-b t}\right)
$$

where $t$ are the days prior to the day of interest (up to 1000 days in our case), $c_{t=0}$ is the amount of litter at the start of each $t$ and $r$ is the initial concentration of litter P. Note that we use this formula with the same decomposition constant for the whole year, in both the wetter and the drier season. It is worth noting that the decomposition experiment took place across rainfall regimes as well, and that precipitation might have a limited impact on decomposition (Sanches et al., 2008).

\section{Soil acid phosphatase}

We used a fluorescence method for analyzing acid phosphatase enzyme activities based on Marx et al. (2001) and calculations from German et al. (2011). Acid phosphatase was assayed in soil slurries of $0.5 \mathrm{~g}$ of fresh soil in $50 \mathrm{ml}$ sodium acetate buffer (pH 5.5) and vortexed for 1 minute before pipetting (200pl) in a black 96-well microplate. As a substrate for acid phosphatases, we used 4-methylumbelliferyl phosphate (M8168 Sigma), with appropriate standard curves (M1381 Sigma) and in addition substrate controls, sample controls and blanks were measured to account for potential quenching effects. Microplates were incubated in the dark for 60 minutes and fluorescence was measured using an Infinite F200 Pro plate reader (Tecan Austria GMBH, Grödig, Austria), with fluorescence intensity measured from the top $\left(\lambda_{\text {excitation }}=360\right.$ and $\left.\lambda_{\text {emission }}=440 \mathrm{~nm}\right)$. Potential extracellular acid phosphatase activities were calculated following German et al. (2011) and are given in $\mu_{\mathrm{mol} \mathrm{g}} \mathrm{g}^{-1} \mathrm{day}^{-1}$, indicating potential activity of the enzyme at substrate saturation on a dry weight basis. 
Statistical analysis

Data organization and calculations were performed with help of the "tidyverse" package (version 1.3.0, Wickham et al., 2019), graphs were made with the package "ggplot2" (version 3.3.2, Wickham, 2016). We calculated daily litter P loss based on the field collections of litter and Eq. (3). For each soil P fraction was evaluated for differences between months and soil depths for each fraction with generalized (glm, base R) or linear mixed models using the lme function from the "nlme" package (version 3.1-148, Pinheiro et al., 2020) with the month and soil depth as fixed factors. We used sample location as a random effect and evaluated the best model fit according to the Akaike information criterion (AIC), and we evaluated the model results. For all fractions, models were allowed different variances per group combination (Month and depth) using the VarIdent variance structure. Because the model fit was better with only the depth included in VarIdent for the inorganic bicarbonate fraction, and month only for the $\mathrm{HCl}$ fraction, those models were fitted with only the mentioned grouping term in the variance structure. The models' residuals were checked for homogeneity and normality and variables were log-transformed if needed.

Since we hypothesized that $\mathrm{P}$ fractions changed over time, we calculated $\Delta \mathrm{P}_{o}$ (the change in $\mathrm{P}_{o}$ fractions between two consecutive sampling dates). The same procedure as above was followed, with the $\Delta \mathrm{P}_{o}$ as response variable, either phosphatase or litter $\mathrm{P}$ loss as the first fixed variable in separate models (since litter P-loss was not location-specific, while phosphatase was), the sample location was added as a random effect if this improved the model fit. A total of eight models were fitted to assess the effects of phosphatase and $\mathrm{P}$ input on the two organic fractions at the two depths. Again, resulting models were validated with visual checks of residuals on homogeneity and normality. All analyses were performed with $\mathrm{R}$ version 3.6.3 ( $\mathrm{R}$ Core Team, 2020).

\section{Results}

\section{Soil P-fractions and their dynamics}

Total soil $\mathrm{P}$ was $143.59 \mu \mathrm{g} \mathrm{g}^{-1}$ for the top $5 \mathrm{~cm}( \pm$ SE 0.55$)$, and $117.72 \mathrm{\mu g} \mathrm{g}^{-1}$ for $5-15 \mathrm{~cm}$ depth ( \pm SE 0.73 , Table 1$)$. The $\mathrm{P}$ concentrations of all except the $\mathrm{HCl}$ and residual fractions, were higher in the top $5 \mathrm{~cm}$ compared to $5-15 \mathrm{~cm}$ soil depth. The extractable inorganic fractions accounted for $29.09 \mathrm{\mu g} \mathrm{g}^{-1}( \pm \mathrm{SE} 0.12$, $20 \%$ of total P) at $0-5 \mathrm{~cm}$, and for $17.39 \mathrm{\mu g} \mathrm{g}^{-1}$ ( \pm SE $0.07,15 \%$ of total P) at $5-15 \mathrm{~cm}$, the organic fractions accounted for $42.47 \mathrm{\mu g} \mathrm{g}^{-1}( \pm \mathrm{SE} 0.34,28 \%$ of $\mathrm{P})$ and $23.32 \mathrm{\mu g} \mathrm{g}^{-1}( \pm \mathrm{SE} 0.16,19 \%)$ respectively. The residual $\mathrm{P}$ accounted for most of the total P, on average 78.43 ( \pm SE $0.56,51 \%)$ at $0-5 \mathrm{~cm}$ and $72.61 \mathrm{\mu g}$ $\mathrm{g}^{-1}( \pm$ SE $0.37,65 \%)$ at $5-15 \mathrm{~cm}$.

Our results show that total soil P fluctuated over the course of the year (Fig. 3 ) and differed between soil depths $(0-5 \mathrm{~cm}$ and $5-15 \mathrm{~cm}$ ) for most fractions (Table 2). Generally, the top $5 \mathrm{~cm}$ had higher $\mathrm{P}$ concentrations, reflected mainly in the extractable $\mathrm{P}$ fractions; the residual fraction did not show a significant effect of soil depth. The most labile fraction, resin $\mathrm{P}$, was higher in the $0-5 \mathrm{~cm}(7.94$, $\pm \mathrm{SE} 0.05)$ as compared to the $5-15 \mathrm{~cm}$ layer $(3.75, \pm \mathrm{SE} 0.03)$ and increased 
from February to May but decreased again until November. The $5-15 \mathrm{~cm}$ resin fraction was significantly larger in February compared to the other months, while November had a significantly smaller resin fraction. The inorganic bicarbonate $\mathrm{P}$ fraction showed some significant differences between months in the topsoil, but those differences were not found at $5-15 \mathrm{~cm}$. For the inorganic hydroxide fraction the November sampling proved significantly lower than the May and August samplings at both depths. The hydrogen chloride fraction had a more diverse pattern, with significantly higher values in February at both soil depths (Table 2).

In contrast to the inorganic $\mathrm{P}$ fractions the organic $\mathrm{P}$ fractions showed a stronger temporal fluctuation. While the $F$ values for the inorganic fractions generally indicate a larger effect size for the sampling depth, the organic fractions generally show a relatively stronger effect of the sampling month, and therefore show a stronger influence of seasonality. We found no direct trade-off between the fractions, e.g., relatively smaller organic fractions did not lead to an increase in the inorganic fractions, but rather varied in roughly the same way across inorganic and organic forms.

The two organic soil $\mathrm{P}$ fractions showed their highest average values in May for both depths (Fig. 3). While other months had lower averages for the organic fractions, not all contrasts were significant. The changes in the organic fractions followed a pattern of a substantial increase in May, and a decline thereafter.

Since the organic fractions showed the clearest variation, we calculated the differences between consecutive sampling dates (Table 3). Between February and May, the organic $\mathrm{P}$ in the top $5 \mathrm{~cm}$ increased by a little over $27 \mathrm{\mu g} \mathrm{g}^{-1}$, almost doubling the size of the organic fractions in 3 months. Between May and August, the organic fractions declined, with no increase in the inorganic pools (Fig. 3). The same pattern can be observed for the $5-15 \mathrm{~cm}$ depth, albeit in lower concentrations. November showed the lowest concentrations of $\mathrm{P}_{o}$, indicating a continued depletion in the dry season.

Litterfall and litter decomposition

The total leaf litterfall amounted to $5377 \mathrm{~kg} \mathrm{ha}^{-1} \mathrm{y}^{-1}$ ( \pm SE 49, or an average of $1.47 \pm \mathrm{SE} 0.01 \mathrm{~g} \mathrm{~m}^{2} \mathrm{day}^{-1}$ ), with a clear peak in September (Fig. 2a), the annual amount of $\mathrm{P}$ in that litter was $0.71 \mathrm{~kg} \mathrm{ha}^{-1} \mathrm{y}^{-1}( \pm \mathrm{SE} 0.01$, or an average of $194.8 \pm \mathrm{SE} 1.8 \mu \mathrm{g} \mathrm{m}^{2}$ day $^{-1}$ ). Litterfall showed a clear seasonal pattern, with a peak at the end of the drier part of the year (August). According to the applied decomposition model, the estimated litter P-loss in 2016 averaged 190.9 ( $\pm \mathrm{SE}$ $0.03) \mathrm{ug} \mathrm{m}^{2}$ day $^{-1}$ (including decomposition of leaf litter produced from previous years), accounting for the time between litterfall and $\mathrm{P}$ mobilization from litter to soil (Fig. 2b). The cumulative modeled $\mathrm{P}$ input over the whole year amounted to $0.69 \mathrm{~kg} \mathrm{ha}^{-1}$; giving a modeled average daily input of $\mathrm{P}$ to the soil of $196 \mu \mathrm{g}$ $\mathrm{m}^{2}$ day $^{-1}( \pm \mathrm{SE} 0.06)$ between February and May, $174 \mu \mathrm{g} \mathrm{m} \mathrm{m}^{2}$ day $^{-1}( \pm \mathrm{SE} 0.04)$ between May and August and $193 \mu \mathrm{g} \mathrm{m} \mathrm{m}^{2}$ day $^{-1}$ ( \pm SE 0.06) between August and November. Overall, in the half time for litter $\mathrm{P}$ was 379 days according to the model, and because decomposition follows an exponential pattern most of this loss took place at the start of decomposition (i.e., with each daily litter input). 
Extracellular acid phosphatase activities

Potential phosphatase activity at $0-5 \mathrm{~cm}$ soil depth amounted to $119.0 \mu \mathrm{mol} \mathrm{g} \mathrm{g}^{-1}$ day $^{-1}\left( \pm\right.$ SE 0.6) on average, at $5-15 \mathrm{~cm}$ the average was $69.9 \mathrm{\mu mol} \mathrm{g}^{-1}$ day $^{-1}$ ( \pm SE 0.5 ). Phosphatase activity ranged from $91.5 \mathrm{mmol} \mathrm{g}^{-1}$ day $^{-1}( \pm \mathrm{SE} \mathrm{1.6})$ in May, to $148.8 \mathrm{\mu mol} \mathrm{g}^{-1} \mathrm{day}^{-1}$ ( \pm SE 1.8) in August (in the topsoil), while the $5-15 \mathrm{~cm}$ depth showed a similar pattern with a lower average of $48.2 \mathrm{\mu mol}$ $\mathrm{g}^{-1}$ day $^{-1}$ ( \pm SE 0.9) in February, to a high $97.9 \mu \mathrm{mol} \mathrm{g}{ }^{-1}$ day $^{-1}$ ( \pm SE 1.4) in August (Fig. 4).

\section{Combining litter, enzyme, and organic P dynamics}

Phosphatase activity was related to the changes in organic $\mathrm{P}\left(\right.$ Delta $\left.\mathrm{P}_{o}\right)$ (Fig. $5 \mathrm{a}, \mathrm{b})$. In the $0-5 \mathrm{~cm}$ depth a negative relationship was observed between the phosphatase and the change in organic bicarbonate $\mathrm{P}(F(1,49)=11.86, p<0.01)$, and a significant negative relationship between phosphatase and the changes in the organic hydroxide fractions $(F(1,46)=16.76, p<0.001)$, while in the $5-15 \mathrm{~cm}$ depth the regression results were not significant, despite following similar pattern as in the top depth.

We evaluated the average $\mathrm{P}$ loss from litter, i.e. $\mathrm{P}$ input to soil, between the sampling dates and its effect on the organic fraction changes (Delta $\mathrm{P}_{o}$ ) (Fig. 5 c, d) as was done with potential phosphatase activity above. The effect of the $\mathrm{P}$ loss from litter on the change in the organic $\mathrm{P}$ fractions was significant, this time for all organic fractions. In the topsoil, the bicarbonate Delta $\mathrm{P}_{o}$ showed a slightly weaker relation to the litter input $(F(1,49)=13, p<0.01)$ than in the $5-15 \mathrm{~cm}$ depth $(F(1,49)=14.27, p<0.01)$ while for the hydroxide DeltaP $\mathrm{P}_{o}$ this relation was slightly stronger at $0-5 \mathrm{~cm}(F(1,49)=16.16, p<0.01)$ compared to the lower depth $(F(1,49)=16.57, p<0.01)$. The phosphatase showed a negative relationship with the change in the organic fractions, whereas the litter inputs before the sampling date showed a positive relation with the change in organic fractions; despite some variation in strength of the response phosphatase decreased the size of the organic fractions, while the litter $\mathrm{P}$ inputs increased the size of the organic fractions.

\section{Discussion}

Overview

In this study we aimed to disentangle the controls over seasonal dynamics of soil $\mathrm{P}$ cycling in a tropical forest, by studying litter inputs to soil, changes of several fractions of soil $\mathrm{P}$ through time, as well as phosphatase activity catalyzing the turnover of organic P. Given that the soils at our study site are highly weathered, we expected that organic $\mathrm{P}$ sources would drive the $\mathrm{P}$ cycling. Our hypothesis that $\mathrm{P}$ availability should vary seasonally was confirmed by clear patterns in seasonal variability of soil $\mathrm{P}$ fractions. Furthermore, we found that soil phosphatase activities were significantly negatively related to net changes in the organic $\mathrm{P}$ fractions at the $0-5 \mathrm{~cm}$ depth (i.e. higher phosphatase activities caused a decline in soil organic 
P), but not significant at 5-15 cm. The decomposition model, relating the observed fluctuations in litter fall to changes in the soil organic $\mathrm{P}$ fraction, confirmed our hypothesis that input of organic $\mathrm{P}$ forms from litter decomposition and associated activities of microbial and plant derived phosphatases were the two main factors controlling soil (organic) P fluctuation in central Amazonian terra-firme forests.

\section{Soil $\mathrm{P}$ pools and turnover}

We found clear indications that the organic $\mathrm{P}$ fraction is the most important component of the local soil $\mathrm{P}$ pool, arguably driving soil $\mathrm{P}_{i}$ availability though mineralization into plant accessible pools. What our data did not show however, is a clear pattern regarding those $\mathrm{P}_{i}$ pools. Our site shows typical values reported for Ferralsols. Quesada et al. (2010) reported that two thirds of the studied soils across the Amazon contain below $100 \mathrm{mg} \mathrm{kg}^{-1}$ extractable P. When comparing our results with other natural ecosystems, the total $\mathrm{P}$ concentration and extractable $\mathrm{P}$ at our study site are low (Cross and Schlesinger, 1995; Johnson et al., 2003; Turner and Engelbrecht, 2011; Yang and Post, 2011), especially if considering the $5-15 \mathrm{~cm}$ soil depth, which is arguably more suitable for comparison since this depth is more representative of mineral soil $\mathrm{P}$ stocks. The top layer plays a more active role in biological (re)cycling and shows larger seasonal fluctuations, and $\mathrm{P}$ decreases rapidly from the top $5 \mathrm{~cm}$ down to $5-15 \mathrm{~cm}$. As Johnson et al. (2003) and others have argued, the controls over labile $\mathrm{P}$ might be less dependent on the soil weathering status (and thus total P) than often assumed; other mechanisms are likely to play a large role, including sorption-desorption dynamics, redox state, and mineralization. According to Helfenstein et al. (2020) the turnover for the extractable inorganic fractions of the Hedley fractionation procedure are minutes to hours for the resin and bicarbonate fractions, while hydroxide fractions have a turnover of days to months, and only hydrochloric acid extractable $\mathrm{P}$ longer. The $\mathrm{P}_{i}$ pools may vary in their bioavailability and since the turnover times of the more available fractions may be fast (Helfenstein et al., 2020), it is likely that we may have missed some of the variation between sampling intervals. The less available (slow turnover) fractions are probably better represented considering the products of mineralization of $\mathrm{P}_{o}$ do not stay in the soil long enough to visibly increase available $\mathrm{P}_{i}$ pools at our sampling frequency.

In a tropical ecosystem, the organic $\mathrm{P}$ fractions are crucial as buffer for the shorter-term $\mathrm{P}$-availability, while actual variability of the (inorganic) ortho-P fractions might be hard to measure in an observational study, especially when Pdemand and thus turnover is high. Organic forms of tropical soil $\mathrm{P}$ constitute about a quarter of total $\mathrm{P}$ according to Turner and Engelbrecht (2011) although there is substantial variation across the Amazon (Quesada et al., 2010). While in this study this proportion is similar overall, we show substantial variation over the year. The relative peak of the organic $\mathrm{P}$ in May, together with the low concentration of organic $\mathrm{P}$ in November (about a factor 2 difference) have large implications suggesting that the organic fraction is the prime regulator of more available forms; if the regulator "stock" of $\mathrm{P}_{o}$ varies, the cycled $\mathrm{P}_{i}$ is likely to be impacted by the same magnitude at shorter time spans. Although the importance of organic $\mathrm{P}$ has been well described and is of central importance to the Walker and Syers model (1976), its annual variation is known to a lesser extent. 
The effect of soil phosphatase and litter decomposition

It has been hypothesized that high phosphatase activity indicates a high $\mathrm{P}$ demand (Allison et al., 2011). Absolute values of soil phosphatase activities at our study site were low compared to global averages (Margalef et al., 2017) which would suggest that $\mathrm{P}$ limitation is not as high as in other (tropical) forests. However, absolute activities might not be the best indicator of nutrient limitation (Moorhead et al., 2016), so it should be used with caution. Interestingly, phosphatase activity was not related to the size of the inorganic $\mathrm{P}$ fractions but rather to the organic fractions. Although this finding might indicate that the (labile) inorganic P fractions are rapidly taken up by plants and microbes, it also suggests that roots and the microbial community and associated enzymatic activities were able to access the organic P-pools and obtain P from there, with the organic P acting as a buffer which stabilizes the P-supply throughout the year. This highlights the importance of $\mathrm{P}$ mineralization from the $\mathrm{P}$ deprived soils in the Central Amazon.

Recent studies conducted in Borneo indicated that the production of phosphatase is demand driven, rather than supply driven (Kitayama, 2013), however, there are alternative hypotheses including a supply-driven philosophy (Turner, 2008), as well as indications that P cycling in tropical forests may be affected by climate, and especially precipitation (Huang et al., 2011; Wood et al., 2016). In this study, it might very well be that the in-situ mineralization rates were generally not limited by climate at any time during the year, but by substrate availability. This would explain a peak in phosphatase activity when the soil organic P fraction is relatively small; the substrate has largely been transformed, what remains is $\mathrm{P}$ demand driving investments in phosphatase, to hydrolyze new $\mathrm{P}_{o}$ substrate. On the other hand, the higher investment in phosphatases could be synchronized with the higher availability of substrate during the annual litter cycle, and therefore variation in enzyme production should be supply- rather than demand-driven. However, due to the nature of nutrient re-cycling between vegetation and soil it is non-trivial to distinguish cause and effect. What we can conclude, however, is that the phosphatase, whether demand-driven, or supply-driven in its activity, is related to the changes in the organic $\mathrm{P}$ fractions and thus to P-availability.

At our site, leaf litterfall increased during the drier season, as has been described for other studies conducted in the region (Luizão, 1989; Wu et al., 2016). Without a doubt, the phosphorus return via litter inputs is crucial to sustain cycling of nutrients within in the forest. Observations underlining the relation between litter inputs and soil organic $\mathrm{P}$ are found for both tropical and temperate forests (Tiessen et al., 1994; Beck and Sanchez, 1994; Chen et al., 2003). The decomposition model has a mediating effect on any peaks observed in the litter and conceptualizes a delay between litterfall and litter soil P input. Even though this model serves well for our purposes and time scale, on shorter timescales decomposition (i.e. litter P loss) can be argued to be more complex and dynamic than our (simple) model; mainly rainfall and soil moisture have controls over the shorterterm dynamics. Moreover, the litter P-loss in inorganic forms might be taken up quickly - something that is beyond the scope of this study. The P input to the soil from decomposition might not be as smooth as the model predicts, but it shows that a simple model for decomposition lines up well with soil $\mathrm{P}$ if integrated over time. 
The dynamic nature of the P-cycle

This study underlines the dynamic nature of the plant soil system regarding $\mathrm{P}$ availability in tropical forest ecosystems. We argue that phosphatase catalyzes the ultimate mineralization step for P. Research in another lowland forest in the Amazon showed the importance of the available bicarbonate and hydroxide fractions in $\mathrm{P}$ cycling as opposed to the more recalcitrant fractions (McGroddy et al., 2008), but the fractions were not differentiated between inorganic and organic forms. Mirabello and colleagues (2013) found a decline in the organic bicarbonate fraction for the dry season in a Panamanian forest (about three times higher total $\mathrm{P}$ compared to our site), which might indicate increased mineralization during that time and thus would support our findings of increased phosphatase activity in the drier months presented in this study. Studies in drier tropical forests also indicate the importance of precipitation in the P-cycle, both in terms of litter dynamics (Valdespino et al., 2009), and sorption of P (Campo et al., 1998).

Overall, our results suggest that soil organic $\mathrm{P}$ pools in highly weathered tropical soils may be more dynamic than previously reported. In low-P soils organic $\mathrm{P}$ inputs are the main source of the nutrient and the biological cycling appears to be highly relevant. Future studies should focus on microbial community dynamics to ultimately identify processes driving P-cycles in tropical forests. Turner et al. (2013) recently highlighted the crucial role of microbial biomass $\mathrm{P}$ in the retention and cycling of $\mathrm{P}$ during ecosystem development, which indicates that microbial community dynamics might be paramount to understanding organic soil $\mathrm{P}$ dynamics in addition to the factors accounted for in this study. Mycorrhizal interactions with different soil fractions and partitioning thereof is adding another layer of complexity to the interaction of $\mathrm{P}$ with the ecosystem (Liu et al., 2018). Although ecosystem models are increasingly recognizing the importance of $\mathrm{P}$ in tropical systems, and starting to implement $\mathrm{P}$ cycle dynamics and processes, a mechanistic understanding of $\mathrm{P}$ in ecosystem processes, is far from complete (Vitousek et al., 2010; Wright et al., 2018). Our results show substantial variability in the soil $\mathrm{P}$ pools during the year, contributing a dynamic representation of the $\mathrm{P}$ cycle and the seasonal pattern of its different components (i.e., soil P-pools) and its drivers.

This dynamic view of the soil $\mathrm{P}$ cycle also indicates a high efficiency of $\mathrm{P}$ cycling, of which the deeper implications point toward a sustained limitation by $\mathrm{P}$ on forest functioning under global change scenarios. In the case of higher levels of $\mathrm{CO}_{2}$, a $\mathrm{P}$ limitation to forest productivity would only become more pronounced. The current tight or closed P-cycle implicates that there is little room for organisms to access more $\mathrm{P}$, and while increased $\mathrm{CO}_{2}$ might stimulate investments belowground - i.e., increased root growth, root exudation including phosphatases - the importance of mineralizing $\mathrm{P}$ from organic compounds limits the amount of $\mathrm{P}$ that could be easily liberated to sustain an acceleration of the P-cycle. Only if the whole cycle intensifies or speeds up - higher return of $\mathrm{P}$ via litter, higher phosphatase activities, higher $\mathrm{P}$ turnover in plants - this new equilibrium would be able to develop, and arguably this acceleration would take place in combination with changes to forest composition. The only way in which this already tight cycle might increase the amount of bioavailable $\mathrm{P}$ in the system would be to access relatively occluded forms of $\mathrm{P}$ by mining in deeper soil layers or by exudation of organic acids to liberate currently unavailable P (Jin et al., 2015), since our results 
point towards little easily accessible $\mathrm{P}$ from soil fractions in the $15 \mathrm{~cm}$. If global changes affect the current seasonality, the tight cycling that is reported here could be susceptible to climate change - leading to $\mathrm{P}$ losses and a less effective cycling of the nutrient. Rapid changes might lead to initial changes in the cycling of $\mathrm{P}$, but on the long run there is little that can be expected to increase the amount of $\mathrm{P}$ cycled from the existing soil $\mathrm{P}$ pools.

\section{Conclusions}

Our study considering the seasonal variation of soil organic $\mathrm{P}$ and its drivers shows how Central Amazonian soil $\mathrm{P}$ fractions may fluctuate inter-annually, in response to root and microbial demand supplying the dynamic organic $\mathrm{P}$ pool. Our study indicates that litter $\mathrm{P}$ inputs and subsequent decomposition increase the soil organic $\mathrm{P}$ pool, while biochemical mineralization through soil enzymes had the opposite effect. Albeit the fact that a tight cycling of $\mathrm{P}$ in tropical forest ecosystems indicates that this nutrient is in short supply, the specific limiting steps are still up for debate, and the observed diametric relationship between different factors within the plant-microbe-soil system further highlights the relevance of studying the P-balance as an integrated dynamic system. 


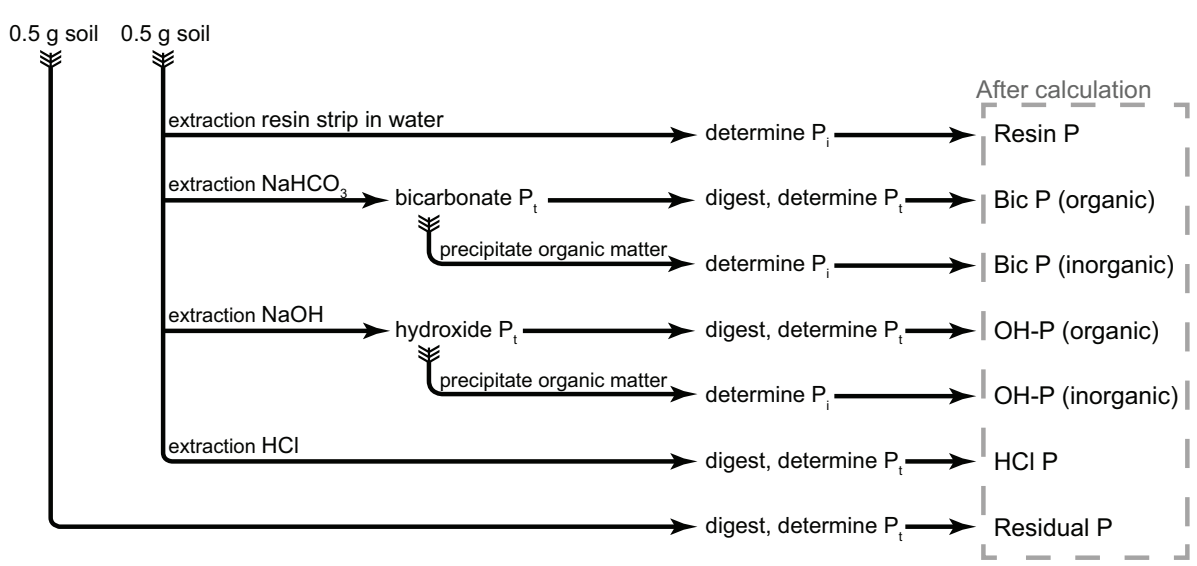

Fig. 1 Schematic view of the Hedley fractionation method for sequential extraction of $\mathrm{P}$, modified from Tiessen and Moir (1993). The organic $\mathrm{P}\left(\mathrm{P}_{o}\right)$ is the difference between the inorganic $\mathrm{P}\left(\mathrm{P}_{i}\right)$ and the total $\mathrm{P}\left(\mathrm{P}_{t}\right)$. The residual fraction is the difference between the total $\mathrm{P}$ from the entire sample and the sum of the extractable fractions. Details in Methods section 'Soil P-fractionation'.
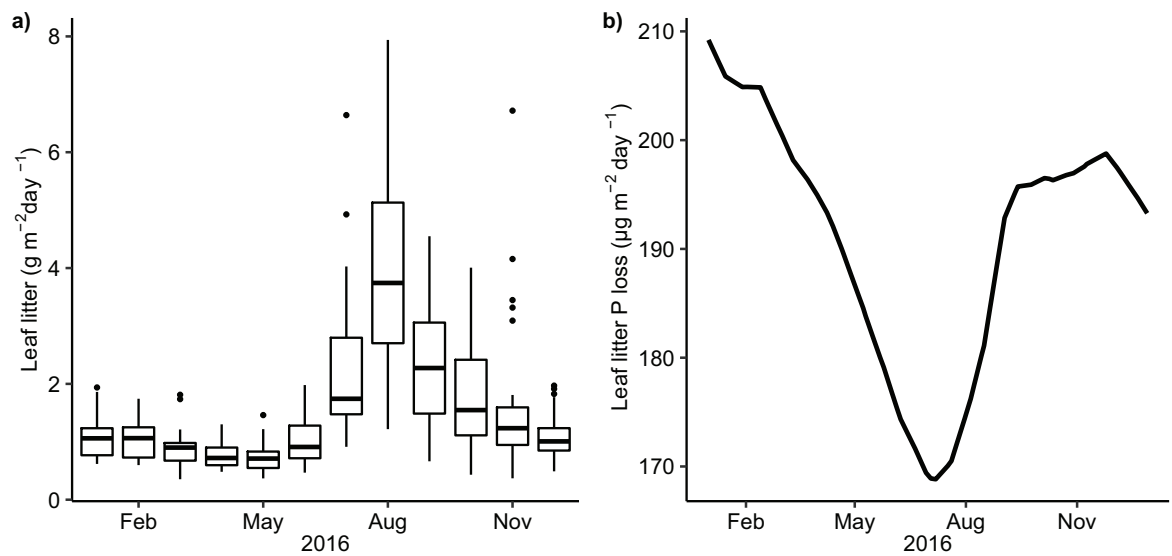

Fig. 2 a) Leaf litter collected at the AmazonFACE study site in 2016, and b) the modeled P-loss from that litter according to Eq. (3), used in this study as soil P-input from litter. Note that the litter data used to calculate this litter P loss is not entirely shown in a) (i.e. pre-2016 data was also used to get soil P-input). Details in Methods section 'Litterfall and P-input'. 

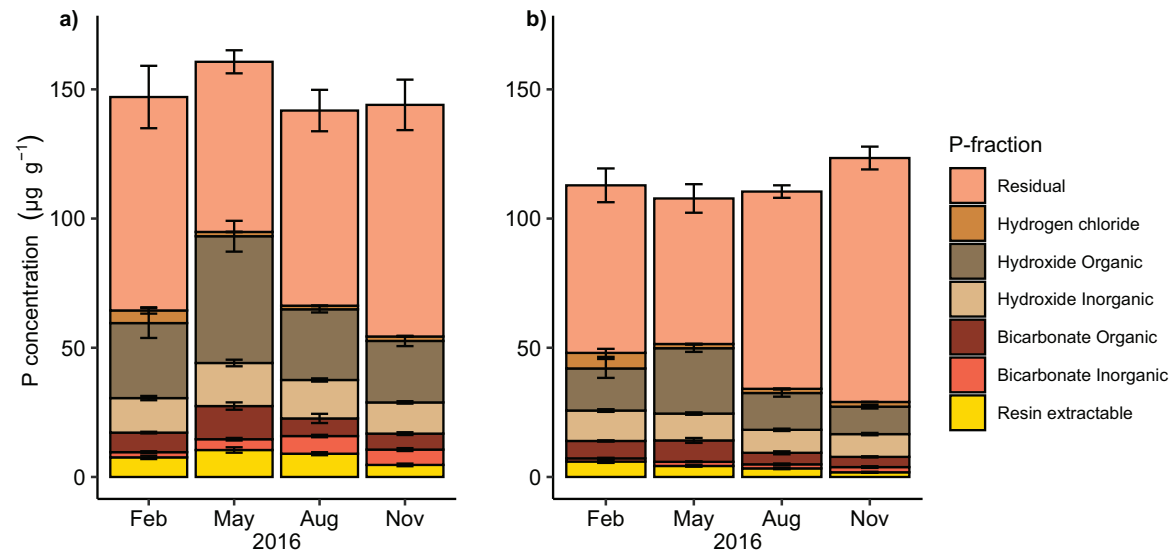

Fig. 3 Cumulative Hedley soil $\mathrm{P}$ fractions determined in 4 campaigns at a) 0-5 cm depth, and b) at $5-15 \mathrm{~cm}$ soil depth. In their sequential extraction order (i.e. first extraction on the bottom, last extraction on top, cumulative bar so the top of the bar represents total $\mathrm{P}$ ). Concentration per dry soil, error bar represents standard error $(n=69)$.
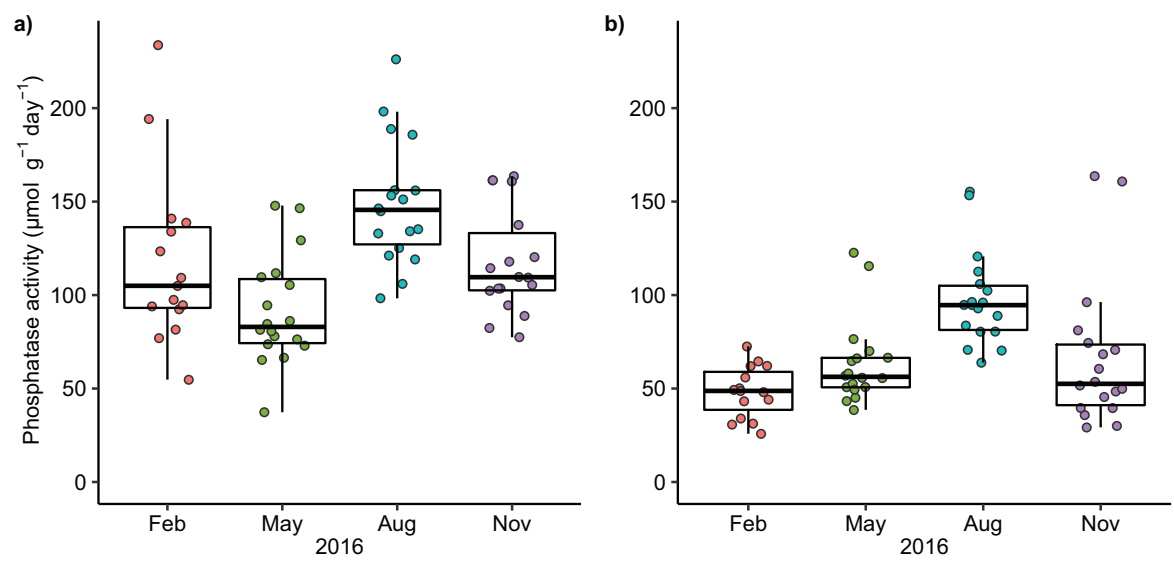

Fig. 4 Potential activities of soil extracellular acid phosphatase at a) $0-5 \mathrm{~cm}$ depth, and b) at $5-15 \mathrm{~cm}$ depth. 

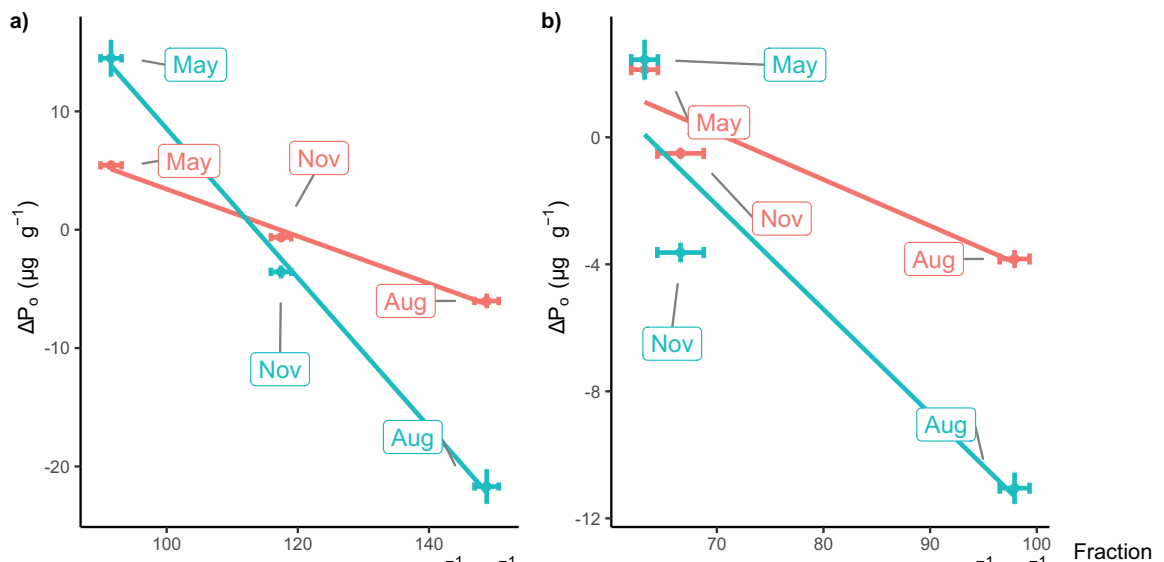

Potential phosphatase activity $\left(\mu \mathrm{mol} \mathrm{g}^{-1}\right.$ day $\left.^{-1}\right)$
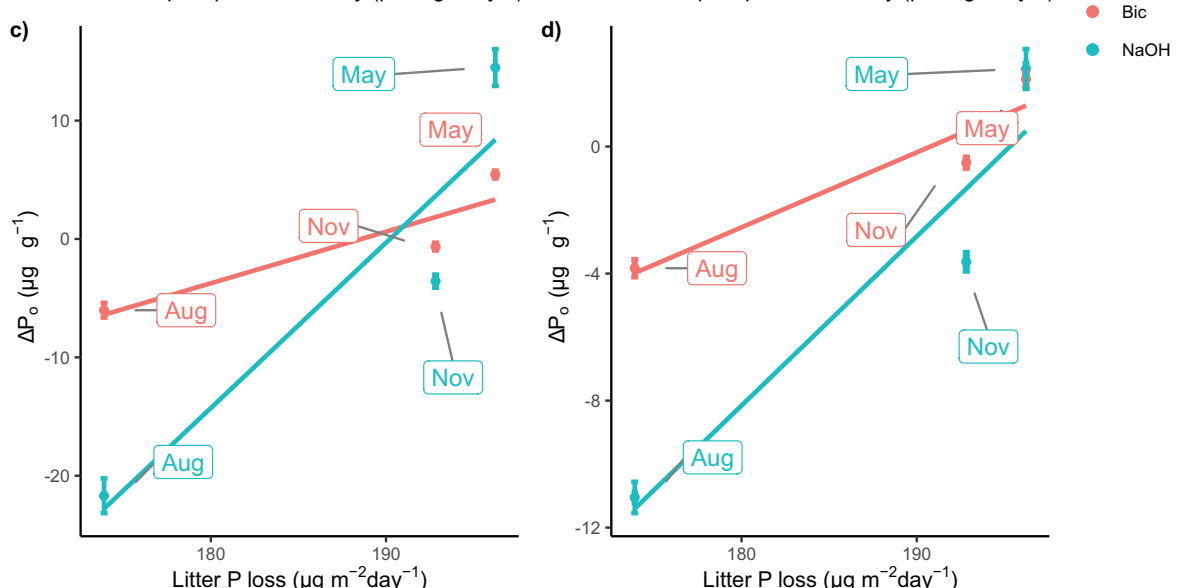

Fig. 5 Relation between average changes in the organic fractions of soil $\mathrm{P}\left(\Delta \mathrm{P}_{o}\right)$, and assumed drivers of those changes. a) relation between average phosphatase and $\Delta \mathrm{P}_{o}$ at $0-5 \mathrm{~cm}$ depth, b) at $5-15 \mathrm{~cm}$ depth, c) the relation of modeled litter inputs (average between sampling dates, 2) with average $\Delta \mathrm{P}_{o}$ at $0-5 \mathrm{~cm}$, and d) at the $5-15 \mathrm{~cm}$ depth. Error bars show the standard error. 
Table 1 Average total $\mathrm{P}$ and soil $\mathrm{P}$ fractions ( $\pm \mathrm{SE}$ ) from the Hedley fractionation, in $\mu \mathrm{gg}^{-1}$, with $n=69$. Details on the extraction procedure in the Methods section 'Soil P-fractionation'.

\begin{tabular}{|c|c|c|c|}
\hline \multicolumn{2}{|c|}{ Fraction } & $0-5 \mathrm{~cm}$ & $5-15 \mathrm{~cm}$ \\
\hline \multicolumn{2}{|c|}{ Total P } & $143.59( \pm 0.61)$ & $112.50( \pm 0.43)$ \\
\hline \multirow{4}{*}{$\mathrm{P}_{i}$} & Resin & $7.94( \pm 0.05)$ & $3.75( \pm 0.03)$ \\
\hline & $\mathrm{NaHCO}_{3}$ & $4.85( \pm 0.04)$ & $1.61( \pm 0.02)$ \\
\hline & $\mathrm{NaOH}$ & $14.31( \pm 0.06)$ & $9.89( \pm 0.03)$ \\
\hline & $\mathrm{HCl}$ & $2.05( \pm 0.02)$ & $2.12( \pm 0.02)$ \\
\hline \multirow{2}{*}{$\mathrm{P}_{o}$} & $\mathrm{NaHCO}_{3}$ & $8.38( \pm 0.08)$ & $5.82( \pm 0.04)$ \\
\hline & $\mathrm{NaOH}$ & $32.03( \pm 0.28)$ & $17.55( \pm 0.13)$ \\
\hline \multicolumn{2}{|c|}{ Residual P } & $78.43( \pm 0.56)$ & $72.61( \pm 0.37)$ \\
\hline
\end{tabular}

Table 2 Analysis of variance $F$ statistics, with $p$ values in parentheses, for each fractions' responses to sampling time (Month), sampling depth (Layer) and their interaction as fixed factors. Includes the sampling location as a random effect where this led to an improved model fit. Only significant values $(p<0.05)$ are shown.

\begin{tabular}{|c|c|c|c|}
\hline & Model terms & $d f$ & $F(p)$ \\
\hline \multirow{4}{*}{ Resin } & Intercept & 1,113 & $819.4(<0.0001)$ \\
\hline & Month & 3,113 & $45.0(<0.0001)$ \\
\hline & Layer & 1,113 & $112.7(<0.0001)$ \\
\hline & Month $x$ Layer & 3,113 & $7.44(0.0001)$ \\
\hline \multirow{4}{*}{$\begin{array}{l}\mathrm{NaHCO}_{3} \\
\text { inorganic }\end{array}$} & Intercept & 1,113 & $146.7(<0.0001)$ \\
\hline & Month & 3,113 & $8.17(0.0001)$ \\
\hline & Layer & 1,113 & $156.5(<0.0001)$ \\
\hline & Month $x$ Layer & 3,113 & $12.9(<0.0001)$ \\
\hline \multirow{4}{*}{$\begin{array}{l}\mathrm{NaHCO}_{3} \\
\text { organic }\end{array}$} & Intercept & 1,113 & $1747(<0.0001)$ \\
\hline & Month & 3,113 & $39.4(<0.0001)$ \\
\hline & Layer & 1,113 & $19.7(<0.0001)$ \\
\hline & Month $x$ Layer & 3,113 & ns \\
\hline \multirow{4}{*}{$\begin{array}{l}\mathrm{NaOH} \\
\text { Inorganic }\end{array}$} & Intercept & 1,112 & $1332(<0.0001)$ \\
\hline & Month & 3,112 & $3.03(0.0322)$ \\
\hline & Layer & 1,112 & $131.5(<0.0001)$ \\
\hline & Month $x$ Layer & 3,112 & $6.50(0.0004)$ \\
\hline \multirow{4}{*}{$\begin{array}{l}\mathrm{NaOH} \\
\text { organic }\end{array}$} & Intercept & 1,113 & $1196(<0.0001)$ \\
\hline & Month & 3,113 & $45.7(<0.0001)$ \\
\hline & Layer & 1,113 & $106.6(<0.0001)$ \\
\hline & Month $x$ Layer & 3,113 & ns \\
\hline \multirow{4}{*}{$\mathrm{HCl}$} & Intercept & 1,113 & $1851(<0.0001)$ \\
\hline & Month & 3,113 & $6.92(0.0001)$ \\
\hline & Layer & 1,113 & $\mathrm{~ns}$ \\
\hline & Month $x$ Layer & 3,113 & $\mathrm{~ns}$ \\
\hline \multirow{4}{*}{ Residual } & Intercept & 1,109 & $1602(<0.0001)$ \\
\hline & Month & 3,109 & $5.77(0.0010)$ \\
\hline & Layer & 1,109 & ns \\
\hline & Month $x$ Layer & 3,109 & ns \\
\hline
\end{tabular}

Table 3 Average change in the organic fractions of $\mathrm{P}\left(\Delta \mathrm{P}_{o}\right)$ in $\mu \mathrm{g} \mathrm{g}^{-1}$, between sampling dates. Standard error between brackets.

\begin{tabular}{|c|c|c|c|c|}
\hline & Change between & $\begin{array}{l}F e b-M a y \\
(n=15)\end{array}$ & $\begin{array}{l}M a y-A u g \\
(n=18)\end{array}$ & $\begin{array}{l}A u g-N o v \\
(n=18)\end{array}$ \\
\hline \multirow{2}{*}{$0-5 \mathrm{~cm}$} & $\mathrm{NaHCO}_{3}$ Organic & $+5.44( \pm 1.52)$ & $-6.02( \pm 2.63)$ & $-0.64( \pm 1.38)$ \\
\hline & NaOH Organic & $+21.78( \pm 7.55)$ & $-21.69( \pm 6.21)$ & $-3.56( \pm 2.32)$ \\
\hline \multirow{2}{*}{$5-15 \mathrm{~cm}$} & $\mathrm{NaHCO}_{3}$ Organic & $+2.13( \pm 1.15)$ & $-3.83( \pm 1.20)$ & $-0.51( \pm 0.74)$ \\
\hline & NaOH Organic & $+8.71( \pm 4.27)$ & $-11.05( \pm 2.09)$ & $-3.63( \pm 1.29)$ \\
\hline
\end{tabular}


Acknowledgements We would like to acknowledge the AmazonFACE program of the National Institute of Amazonian Research (INPA), which was funded by the Inter-American Development Bank (IADB) through a technical cooperation agreement with the Brazilian Ministry of Science, Technology, Innovation and Communications (MCTI) Grant BR-T1284, by Brazil's Coordination for the Improvement of Higher Education Personnel (CAPES) Grant 23038.007722/2014-77 and Grant CAPES-INPA/88881.154644/2017-01, and by Amazonas Research Foundation (FAPEAM) Grant 2649/2014. Additional funding was provided by the Brazilian National Council for Scientific and Technological Development (CNPq) Grant CNPq/LBA 68/2013. KS was supported by a CNPq/LBA 68/2013 PCI grant and after by the AmazonFACE program with a CAPES scholarship. LF was supported by the European Union's Horizon 2020 research and innovation program under the Marie Sklodovska-Curie grant agreement No 847693 (REWIRE). LFL was supported by the AmazonFACE program with CAPES-INPA Grant 88887.154643/2017-00.

The authors thank Luciano Castilho for logistic support, Erison Gomes for assistance with lab work, and Richard Norby for suggestions on an earlier draft. We are thankful to the AmazonFACE-team, the crew at the ZF2 field site, and the LTSP laboratory for general support.

\section{Declarations}

\section{Funding}

The research was funded by the AmazonFACE program of INPA, and by CNPq under grant CNPq/LBA 68/2013. The AmazonFACE program received funding through the IADB in a technical cooperation agreement with the MCTI Grant BRT1284, by CAPES Grant 23038.007722/2014-77 and CAPES-INPA/88881.154644/201701, and by FAPEAM Grant 2649/2014. Individual funding of authors is mentioned in the acknowledgements.

\section{Authors' contributions}

KJS, LF, MRH, and CAQ conceptualized the research. Experiments were carried out by KS, LF and NPM, with field support from FH and OVB. Data analyses were performed by KJS, with support from LF and FH. KS prepared the manuscript, with contributions from all authors.

Availability of data and material

Data used in this manuscript will be made available on a public repository upon publication

\section{Conflict of interest}

The authors declare no conflict of interest. 


\section{References}

Allison SD, Weintraub MN, Gartner TB, Waldrop MP (2011) EvolutionaryEconomic Principles as Regulators of Soil Enzyme Production and Ecosystem Function. In: Shukla G, Varma A (eds) Soil Enzymol., vol 64, pp 229-243, https://doi.org/10.1007/978-3-642-14225-3_12

Aragão LEOC, Malhi Y, Metcalfe DB, Silva-Espejo JE, Jiménez E, Navarrete D, Almeida S, Costa aCL, Salinas N, Phillips OL, Anderson LO, Baker TR, Goncalvez PH, Huamán-Ovalle J, Mamani-Solórzano M, Meir P, Monteagudo A, Peñuela MC, Prieto A, Quesada Ca, Rozas-Dávila A, Rudas A, Silva Junior Ja, Vásquez R (2009) Above- and below-ground net primary productivity across ten Amazonian forests on contrasting soils. Biogeosciences Discuss 6(1):24412488, https://doi.org/10.5194/bgd-6-2441-2009

Araújo AC, Nobre AD, Kruijt B, Elbers JA, Dallarosa R, Stefani P, Von Randow C, Manzi AO, Culf AD, Gash JHC, Valentini R, Kabat P (2002) Comparative measurements of carbon dioxide fluxes from two nearby towers in a central Amazonian rainforest: The Manaus LBA site. J Geophys Res 107:1-20, https://doi.org/10.1029/2001JD000676

Beck MA, Sanchez PA (1994) Soil Phosphorus Fraction Dynamics during 18 Years of Cultivation on a Typic Paleudult. Soil Sci Soc Am J 58(5):1424-1431, https://doi.org/10.2136/sssaj1994.03615995005800050021x

Brienen RJW, Phillips OL, Feldpausch TR, Gloor E, Baker TR, Lloyd J, LopezGonzalez G, Monteagudo-Mendoza A, Malhi Y, Lewis SL, Vásquez Martinez R, Alexiades M, Álvarez Dávila E, Alvarez-Loayza P, Andrade A, Aragão LEOC, Araujo-Murakami A, Arets EJMM, Arroyo L, Aymard C GA, Bánki OS, Baraloto C, Barroso J, Bonal D, Boot RGA, Camargo JLC, Castilho CV, Chama V, Chao KJ, Chave J, Comiskey JA, Cornejo Valverde F, da Costa L, de Oliveira EA, Di Fiore A, Erwin TL, Fauset S, Forsthofer M, Galbraith DR, Grahame ES, Groot N, Hérault B, Higuchi N, Honorio Coronado EN, Keeling H, Killeen TJ, Laurance WF, Laurance S, Licona J, Magnussen WE, Marimon BS, MarimonJunior BH, Mendoza C, Neill DA, Nogueira EM, Núñez P, Pallqui Camacho NC, Parada A, Pardo-Molina G, Peacock J, Peña-Claros M, Pickavance GC, Pitman NCA, Poorter L, Prieto A, Quesada CA, Ramírez F, Ramírez-Angulo H, Restrepo Z, Roopsind A, Rudas A, Salomão RP, Schwarz M, Silva N, Silva-Espejo JE, Silveira M, Stropp J, Talbot J, ter Steege H, Teran-Aguilar J, Terborgh J, Thomas-Caesar R, Toledo M, Torello-Raventos M, Umetsu RK, van der Heijden GMF, van der Hout P, Guimarães Vieira IC, Vieira SA, Vilanova E, Vos VA, Zagt RJ (2015) Long-term decline of the Amazon carbon sink. Nature 519(7543):344-348, https://doi.org/10.1038/nature14283

Buendía C, Arens S, Hickler T, Higgins SI, Porada P, Kleidon A (2014) On the potential vegetation feedbacks that enhance phosphorus availability - Insights from a process-based model linking geological and ecological timescales. Biogeosciences 11(13):3661-3683, https://doi.org/10.5194/bg-11-3661-2014

Cabugao KG, Yaffar D, Stenson N, Childs J, Phillips J, Mayes MA, Yang X, Weston DJ, Norby RJ (2021) Bringing function to structure: Root-soil interactions shaping phosphatase activity throughout a soil profile in Puerto Rico. Ecol Evol 11(3):1150-1164, https://doi.org/10.1002/ece3.7036

Campo J, Jaramillo VJ, Maass JM (1998) Pulses of soil phosphorus availability in a Mexican tropical dry forest: Effects of seasonality and level of wetting. 
Oecologia 115(1-2):167-172, https://doi.org/10.1007/s004420050504

Chave J, Navarrete D, Almeida S, Álvarez E, Aragão LEOC, Bonal D, Châtelet P, Silva-Espejo JE, Goret JY, von Hildebrand P, Jiménez E, Patiño S, Peñuela MC, Phillips OL, Stevenson P, Malhi Y (2010) Regional and seasonal patterns of litterfall in tropical South America. Biogeosciences 7(1):43-55, https://doi.org/ 10.5194/bg-7-43-2010

Chen CR, Condron LM, Davis MR, Sherlock RR (2003) Seasonal changes in soil phosphorus and associated microbial properties under adjacent grassland and forest in New Zealand. For Ecol Manage 177(1-3):539-557, https://doi.org/ 10.1016/S0378-1127(02)00450-4

Cross AF, Schlesinger WH (1995) A literature review and evaluation of the. Hedley fractionation: Applications to the biogeochemical cycle of soil phosphorus in natural ecosystems. Geoderma 64(3-4):197-214, https://doi.org/10.1016/00167061(94)00023-4

Darch T, Blackwell MS, Chadwick D, Haygarth PM, Hawkins JM, Turner BL (2016) Assessment of bioavailable organic phosphorus in tropical forest soils by organic acid extraction and phosphatase hydrolysis. Geoderma 284:93-102, https://doi.org/10.1016/j.geoderma.2016.08.018

Du E, Terrer C, Pellegrini AF, Ahlström A, van Lissa CJ, Zhao X, Xia N, Wu $\mathrm{X}$, Jackson RB (2020) Global patterns of terrestrial nitrogen and phosphorus limitation. Nat Geosci https://doi.org/10.1038/s41561-019-0530-4

Fleischer K, Rammig A, De Kauwe MG, Walker AP, Domingues TF, Fuchslueger L, Garcia S, Goll DS, Grandis A, Jiang M, Haverd V, Hofhansl F, Holm JA, Kruijt B, Leung F, Medlyn BE, Mercado LM, Norby RJ, Pak B, von Randow C, Quesada CA, Schaap KJ, Valverde-Barrantes OJ, Wang YP, Yang X, Zaehle S, Zhu Q, Lapola DM (2019) Amazon forest response to CO2 fertilization dependent on plant phosphorus acquisition. Nat Geosci 12(9):736-741, https://doi.org/10.1038/s41561-019-0404-9

German DP, Weintraub MN, Grandy aS, Lauber CL, Rinkes ZL, Allison SD (2011) Optimization of hydrolytic and oxidative enzyme methods for ecosystem studies. Soil Biol Biochem 43(7):1387-1397, https://doi.org/ 10.1016/j.soilbio.2011.03.017

Hedley MJ, Stewart JWB, Chauhan BS (1982) Changes in Inorganic and Organic Soil Phosphorus Fractions Induced by Cultivation Practices and by Laboratory Incubations. Soil Sci Soc Am J 46(5):970, https://doi.org/ 10.2136/sssaj1982.03615995004600050017x

Helfenstein J, Pistocchi C, Oberson A, Tamburini F, Goll DS, Frossard E (2020) Estimates of mean residence times of phosphorus in commonly considered inorganic soil phosphorus pools. Biogeosciences 17(2):441-454, https://doi.org/ $10.5194 /$ bg-17-441-2020

Herrera R, Jordan CF, Klinge H, Medina E (1978) Amazon ecosystems. Their structure and functioning with particular emphasis on nutrients. Interciencia $3(4): 223-231$

Hinsinger P (2001) Bioavailability of soil inorganic P in the rhizosphere as affected by root-induced chemical changes: a review. Plant Soil 237:173-195, https://doi.org/10.1023/a:1013351617532

Hofhansl F, Chacón-Madrigal E, Fuchslueger L, Jenking D, Morera-Beita A, Plutzar C, Silla F, Andersen KM, Buchs DM, Dullinger S, Fiedler K, Franklin O, Hietz P, Huber W, Quesada CA, Rammig A, Schrodt F, Vincent AG, Weis- 
senhofer A, Wanek W (2020) Climatic and edaphic controls over tropical forest diversity and vegetation carbon storage. Sci Rep 10(1):5066, https://doi.org/ 10.1038/s41598-020-61868-5

Huang W, Liu J, Zhou G, Zhang D, Deng Q (2011) Effects of precipitation on soil acid phosphatase activity in three successional forests in southern China. Biogeosciences 8(7):1901-1910, https://doi.org/10.5194/bg-8-1901-2011

Hubau W, Lewis SL, Phillips OL, Affum-Baffoe K, Beeckman H, Cuní-Sanchez A, Daniels AK, Ewango CE, Fauset S, Mukinzi JM, Sheil D, Sonké B, Sullivan MJ, Sunderland TC, Taedoumg H, Thomas SC, White LJ, Abernethy KA, AduBredu S, Amani CA, Baker TR, Banin LF, Baya F, Begne SK, Bennett AC, Benedet F, Bitariho R, Bocko YE, Boeckx P, Boundja P, Brienen RJ, Brncic T, Chezeaux E, Chuyong GB, Clark CJ, Collins M, Comiskey JA, Coomes DA, Dargie GC, de Haulleville T, Kamdem MND, Doucet JL, Esquivel-Muelbert A, Feldpausch TR, Fofanah A, Foli EG, Gilpin M, Gloor E, Gonmadje C, GourletFleury S, Hall JS, Hamilton AC, Harris DJ, Hart TB, Hockemba MB, Hladik A, Ifo SA, Jeffery KJ, Jucker T, Yakusu EK, Kearsley E, Kenfack D, Koch A, Leal ME, Levesley A, Lindsell JA, Lisingo J, Lopez-Gonzalez G, Lovett JC, Makana JR, Malhi Y, Marshall AR, Martin J, Martin EH, Mbayu FM, Medjibe VP, Mihindou V, Mitchard ET, Moore S, Munishi PK, Bengone NN, Ojo L, Ondo FE, Peh KS, Pickavance GC, Poulsen AD, Poulsen JR, Qie L, Reitsma J, Rovero F, Swaine MD, Talbot J, Taplin J, Taylor DM, Thomas DW, Toirambe B, Mukendi JT, Tuagben D, Umunay PM, van der Heijden GM, Verbeeck H, Vleminckx J, Willcock S, Wöll H, Woods JT, Zemagho L (2020) Asynchronous carbon sink saturation in African and Amazonian tropical forests. Nature 579(7797):80-87, https://doi.org/10.1038/s41586-020-2035-0

Jin J, Tang C, Sale P (2015) The impact of elevated carbon dioxide on the phosphorus nutrition of plants: A review. Ann Bot 116(6):987-999, https://doi.org/ $10.1093 / \mathrm{aob} / \mathrm{mcv} 088$

Johnson AH, Frizano J, Vann DR (2003) Biogeochemical implications of labile phosphorus in forest soils determined by the Hedley fractionation procedure. Oecologia 135(4):487-499, https://doi.org/10.1007/s00442-002-1164-5

Johnson DW, Cole DW (1980) Anion mobility in soils: Relevance to nutrient transport from forest ecosystems. Environ Int 3(1):79-90, https://doi.org/ 10.1016/0160-4120(80)90040-9

Kitayama K (2013) The activities of soil and root acid phosphatase in the nine tropical rain forests that differ in phosphorus availability on Mount Kinabalu, Borneo. Plant Soil 367(1-2):215-224, https://doi.org/10.1007/s11104-013-16241

Krishna MP, Mohan M (2017) Litter decomposition in forest ecosystems: a review. Energy, Ecol Environ 2(4):236-249, https://doi.org/10.1007/s40974-017-0064-9

Liu X, Burslem DF, Taylor JD, Taylor AF, Khoo E, Majalap-Lee N, Helgason T, Johnson D (2018) Partitioning of soil phosphorus among arbuscular and ectomycorrhizal trees in tropical and subtropical forests. Ecol Lett 21(5):713723, https://doi.org/10.1111/ele.12939

Lloyd J, Bird M, Veenendaal E, Kruijt B (2001) Should Phosphorus Availability Be Constraining Moist Tropical Forest Responses to Increasin CO2 Concentrations. In: Schulze ED, Heimann M, Harrison S, Holland E, Lloyd J, Prentice IC, Schimel D (eds) Global Biogeochemical Cycles in the Climate System, JANUARY, Academic Press, San Diego, chap 1.8, pp 95-114, https://doi.org/ 
10.1016/B978-012631260-7/50010-8

Lugli LF, Andersen KM, Aragão LE, Cordeiro AL, Cunha HFV, Fuchslueger L, Meir P, Mercado LM, Oblitas E, Quesada CA, Rosa JS, Schaap KJ, ValverdeBarrantes O, Hartley IP (2020) Multiple phosphorus acquisition strategies adopted by fine roots in low-fertility soils in Central Amazonia. Plant Soil 450(12), https://doi.org/10.1007/s11104-019-03963-9

Luizão FJ (1989) Litter production and mineral element input to the forest floor in a Central Amazonian forest. GeoJournal 19(4):407-417, https://doi.org/ 10.1007/BF00176910

Luizão FJ, Schubart HOR (1987) Litter production and decomposition in a terrafirme forest of Central Amazonia. Experientia 43(3):259-265, https://doi.org/ 10.1007/BF01945549

Margalef O, Sardans J, Fernández-Martínez M, Molowny-Horas R, Janssens IA, Ciais P, Goll D, Richter A, Obersteiner M, Asensio D, Peñuelas J (2017) Global patterns of phosphatase activity in natural soils. Sci Rep 7(1):1-13, https://doi.org/10.1038/s41598-017-01418-8

Martins N, Fuchslueger L, Fleisher K, Andersen K, Assis RL, Baccaro F, Camargo P, Cordeiro A, Grandis A, Hartley I, Hofhansl F, Lugli L, Lapola DM, Menezes J, Norby RJ, Rammig A, Rosa J, Schaap K, Takeshi B, Valverde-Barrantes OJ, Quesada C (2021) Fine roots stimulate nutrient release during early stages of leaf litter decomposition in a Central Amazon rainforest [Manuscript submitted for publication, in review]

Marx MC, Wood M, Jarvis SC (2001) A microplate fluorimetric assay for the study of enzyme diversity in soils. Soil Biol Biochem 33(12-13):1633-1640, https://doi.org/10.1016/S0038-0717(01)00079-7

Mayaux P, Holmgren P, Achard F, Eva HD, Stibig HJJ, Branthomme A (2005) Tropical forest cover change in the 1990s and options for future monitoring. Philos Trans R Soc Lond B Biol Sci 360(1454):373-84, https://doi.org/ $10.1098 /$ rstb.2004.1590

McGechan MB, Lewis DR (2002) Sorption of phosphorus by soil, part 1: Principles, equations and models. Biosyst Eng 82(1):1-24, https://doi.org/ 10.1006/bioe.2002.0054

McGroddy ME, Silver WL, de Oliveira JC, de Mello WZ, Keller M (2008) Retention of phosphorus in highly weathered soils under a lowland Amazonian forest ecosystem. J Geophys Res Biogeosciences 113(4):1-11, https://doi.org/ 10.1029/2008JG000756

Mirabello MJ, Yavitt JB, Garcia M, Harms KE, Turner BL, Wright SJ (2013) Soil phosphorus responses to chronic nutrient fertilisation and seasonal drought in a humid lowland forest, Panama. Soil Res 51(3):215-221, https://doi.org/ 10.1071/SR12188

Moorhead DL, Sinsabaugh RL, Hill BH, Weintraub MN (2016) Vector analysis of ecoenzyme activities reveal constraints on coupled $\mathrm{c}, \mathrm{n}$ and $\mathrm{p}$ dynamics. Soil Biology and Biochemistry 93:1-7, https://doi.org/10.1016/j.soilbio.2015.10.019

Murphy J, Riley JP (1962) A modified single solution method for the determination of phosphate in natural waters. Anal Chim Acta 27(C):31-36, https://doi.org/10.1016/S0003-2670(00)88444-5, arXiv:1011.1669v3

Nasto MK, Alvarez-Clare S, Lekberg Y, Sullivan BW, Townsend AR, Cleveland CC (2014) Interactions among nitrogen fixation and soil phosphorus acquisition strategies in lowland tropical rain forests. Ecol Lett 17(10):1282-1289, 
$721 \quad$ https://doi.org/10.1111/ele.12335

722 Nasto MK, Osborne BB, Lekberg Y, Asner GP, Balzotti CS, Porder S, Taylor

723 PG, Townsend AR, Cleveland CC (2017) Nutrient acquisition, soil phosphorus 724 partitioning and competition among trees in a lowland tropical rain forest. New 725 Phytol 214(4):1506-1517, https://doi.org/10.1111/nph.14494

726 Olson JS (1963) Energy Storage and the Balance of Producers and Decomposers in Ecological Systems. Ecology 44(2):322-331, https://doi.org/10.2307/1932179

Oren R, Ellsworth DS, Johnsen KH, Phillips N, Ewers BE, Maier C, Schafer KVR, McCarthy H, Hendrey G, McNulty SG, Katul GG, Schäfer KV, McCarthy H, Hendrey G, McNulty SG, Katul GG (2001) Soil fertility limits carbon sequestration by forest ecosystems in a CO2-enriched atmosphere. Nature 411(6836):469472, https://doi.org/10.1038/35078064

Pan Y, Birdsey RA, Fang J, Houghton R, Kauppi PE, Kurz WA, Phillips OL, Shvidenko A, Lewis SL, Canadell JG, Ciais P, Jackson RB, Pacala SW, McGuire AD, Piao S, Rautiainen A, Sitch S, Hayes D (2011) A Large and Persistent Carbon Sink in the World's Forests. Science (80- ) 333(6045):988-993, https://doi.org/ 10.1126/science. 1201609

Pereira IS, do Nascimento HE, Vicari MB, Disney M, DeLucia EH, Domingues T, Kruijt B, Lapola D, Meir P, Norby RJ, Ometto JP, Quesada CA, Rammig A, Hofhansl F (2019) Performance of laser-based electronic devices for structural analysis of Amazonian terra-firme forests. Remote Sens 11(5), https://doi.org/ $10.3390 / \mathrm{rs} 11050510$

Pinheiro J, Bates D, DebRoy S, Sarkar D, R Core Team (2020) nlme: Linear and Nonlinear Mixed Effects Models. URL https://CRAN.Rproject.org $/$ package $=$ nlme

Quesada CA, Lloyd J, Schwarz M, Patiño S, Baker TR, Czimczik C, Fyllas NM, Martinelli L, Nardoto GB, Schmerler J, Santos aJB, Hodnett MG, Herrera R, Luizão FJ, Arneth A, Lloyd G, Dezzeo N, Hilke I, Kuhlmann I, Raessler M, Brand Wa, Geilmann H, Filho JOM, Carvalho FP, Filho RNA, Chaves JE, Cruz OF, Pimentel TP, Paiva R (2010) Variations in chemical and physical properties of Amazon forest soils in relation to their genesis. Biogeosciences 7(5):1515-1541, https://doi.org/10.5194/bg-7-1515-2010

Quesada CA, Lloyd J, Anderson LO, Fyllas NM, Schwarz M, Czimczik CI (2011) Soils of Amazonia with particular reference to the RAINFOR sites. Biogeosciences 8(6):1415-1440, https://doi.org/10.5194/bg-8-1415-2011

Quesada CA, Phillips OL, Schwarz M, Czimczik CI, Baker TR, Patiño S, Fyllas NM, Hodnett MG, Herrera R, Almeida S, Alvarez Dávila E, Arneth A, Arroyo L, Chao KJ, Dezzeo N, Erwin T, Di Fiore A, Higuchi N, Honorio Coronado E, Jimenez EM, Killeen T, Lezama aT, Lloyd G, Löpez-González G, Luizão FJ, Malhi Y, Monteagudo A, Neill Da, Núñez Vargas P, Paiva R, Peacock J, Peñuela MC, Peña Cruz A, Pitman N, Priante Filho N, Prieto A, Ramírez H, Rudas A, Salomão R, Santos aJB, Schmerler J, Silva N, Silveira M, Vásquez R, Vieira I, Terborgh J, Lloyd J (2012) Basin-wide variations in Amazon forest structure and function are mediated by both soils and climate. Biogeosciences 9(6):2203-2246, https://doi.org/10.5194/bg-9-2203-2012

R Core Team (2020) R: A Language and Environment for Statistical Computing. Vienna, Austria, 3rd edn, URL https://www.R-project.org/

Raven JA, Lambers H, Smith SE, Westoby M (2018) Costs of acquiring phosphorus by vascular land plants: patterns and implications for plant coexistence. New 
Phytol 217(4):1420-1427, https://doi.org/10.1111/nph.14967

771 Richardson AE, Lynch JP, Ryan PR, Delhaize E, Smith FA, Smith SE, Harvey PR, Ryan MH, Veneklaas EJ, Lambers H, Oberson A, Culvenor RA, Simpson RJ (2011) Plant and microbial strategies to improve the phosphorus efficiency of agriculture. Plant Soil 349(1-2):121-156, https://doi.org/10.1007/s11104-0110950-4

Roberts K, Defforey D, Turner BL, Condron LM, Peek S, Silva S, Kendall C, Paytan A (2015) Oxygen isotopes of phosphate and soil phosphorus cycling across a 6500year chronosequence under lowland temperate rainforest. Geoderma 257258:14-21, https://doi.org/10.1016/j.geoderma.2015.04.010

Sanches L, Valentini CMA, Pinto Júnior OB, Nogueira JdS, Vourlitis GL, Biudes MS, da Silva CJ, Bambi P, Lobo FdA (2008) Seasonal and interannual litter dynamics of a tropical semideciduous forest of the southern Amazon Basin, Brazil. J Geophys Res Biogeosciences 113(4):1-9, https://doi.org/ 10.1029/2007JG000593

Stark NM, Jordan CF (1978) Nutrient Retention by the Root Mat of an Amazonian Rain Forest. Ecology 59(3):434-437, https://doi.org/10.2307/1936571

Steidinger BS, Turner BL, Corrales AA, Dalling JW (2015) Variability in potential to exploit different soil organic phosphorus compounds among tropical montane tree species. Funct Ecol 29(1):121-130, https://doi.org/10.1111/13652435.12325

Terrer C, Jackson RB, Prentice IC, Keenan TF, Kaiser C, Vicca S, Fisher JB, Reich PB, Stocker BD, Hungate BA, Peñuelas J, McCallum I, Soudzilovskaia NA, Cernusak LA, Talhelm AF, Van Sundert K, Piao S, Newton PC, Hovenden MJ, Blumenthal DM, Liu YY, Müller C, Winter K, Field CB, Viechtbauer W, Van Lissa CJ, Hoosbeek MR, Watanabe M, Koike T, Leshyk VO, Polley HW, Franklin O (2019) Nitrogen and phosphorus constrain the CO2 fertilization of global plant biomass. Nat Clim Chang 9(9):684-689, https://doi.org/ $10.1038 / \mathrm{s} 41558-019-0545-2$

Tiessen H (2008) Phosphorus in the global environment. In: Ecophysiol. PlantPhosphorus Interact., pp 1-7, https://doi.org/10.1007/978-1-4020-8435-5_1

Tiessen H, Moir JO (1993) Characterization of Available P by Sequential Extraction. In: Carter MR (ed) Soil sampling and methods of Analysis, vol 7, Lewis Publishers, Boca Raton, FL, chap 10, pp 75-86

Tiessen H, Cuevas E, Chacon P (1994) The role of soil organic matter in sustaining soil fertility. Nature 371(6500):783-785, https://doi.org/10.1038/371783a0

Townsend AR, Cleveland CC, Houlton BZ, Alden CB, White JWC (2011) Multielement regulation of the tropical forest carbon cycle. Front Ecol Environ 9(1):917, https://doi.org/10.1890/100047

Turner BL (2008) Resource partitioning for soil phosphorus: A hypothesis. J Ecol 96(4):698-702, https://doi.org/10.1111/j.1365-2745.2008.01384.x

Turner BL, Engelbrecht BM (2011) Soil organic phosphorus in lowland tropical rain forests. Biogeochemistry 103(1):297-315, https://doi.org/10.1007/s10533010-9466-x

Turner BL, Condron LM, Richardson SJ, Peltzer DA, Allison VJ (2007) Soil organic phosphorus transformations during pedogenesis. Ecosystems 10(7):11661181, https://doi.org/10.1007/s10021-007-9086-z

Turner BL, Lambers H, Condron LM, Cramer MD, Leake JR, Richardson AE, Smith SE (2013) Soil microbial biomass and the fate of phosphorus during 
long-term ecosystem development. Plant Soil 367(1-2):225-234, https://doi.org/ 10.1007/s11104-012-1493-z

Valdespino P, Romualdo R, Cadenazzi L, Campo J (2009) Phosphorus cycling in primary and secondary seasonally dry tropical forests in Mexico. Ann For Sci 66(1):107-107, https://doi.org/10.1051/forest:2008075

Vance CP, Uhde-Stone C, Allan DL (2003) Phosphorus acquisition and use: Critical adaptations by plants for securing a nonrenewable resource. New Phytol 157(3):423-447, https://doi.org/10.1046/j.1469-8137.2003.00695.x

Vitousek P (1982) Nutrient Cycling and Nutrient Use Efficiency. Am Nat 119(4):553-572, https://doi.org/10.1086/283931

Vitousek PM (1984) Litterfall, Nutrient Cycling, and Nutrient Limitation in Tropical Forests. Ecology 65(1):285, https://doi.org/10.2307/1939481

Vitousek PM, Porder S, Houlton BZ, Chadwick OA (2010) Terrestrial phosphorus limitation: mechanisms, implications, and nitrogen-phosphorus interactions. Ecol Appl 20(1):5-15, https://doi.org/10.1890/08-0127.1

Walker T, Syers J (1976) The fate of phosphorus during pedogenesis. Geoderma 15(1):1-19, https://doi.org/10.1016/0016-7061(76)90066-5

Wickham H (2016) ggplot2: Elegant Graphics for Data Analysis. Springer-Verlag New York, URL https://ggplot2.tidyverse.org

Wickham H, Averick M, Bryan J, Chang W, McGowan L, François R, Grolemund G, Hayes A, Henry L, Hester J, Kuhn M, Pedersen T, Miller E, Bache S, Müller K, Ooms J, Robinson D, Seidel D, Spinu V, Takahashi K, Vaughan D, Wilke C, Woo K, Yutani H (2019) Welcome to the Tidyverse. J Open Source Softw 4(43):1686, https://doi.org/10.21105/joss.01686

Wood TE, Matthews D, Vandecar K, Lawrence D (2016) Short-term variability in labile soil phosphorus is positively related to soil moisture in a humid tropical forest in Puerto Rico. Biogeochemistry 127(1):35-43, https://doi.org/ 10.1007/s10533-015-0150-z

Wright SJ, Turner BL, Yavitt JB, Harms KE, Kaspari M, Tanner EV, Bujan J, Griffin EA, Mayor JR, Pasquini SC, Sheldrake M, Garcia MN (2018) Plant responses to fertilization experiments in lowland, species-rich, tropical forests. Ecology 99(5):1129-1138, https://doi.org/10.1002/ecy.2193

Wu J, Albert LP, Lopes AP, Restrepo-Coupe N, Hayek M, Wiedemann KT, Guan K, Stark SC, Christoffersen B, Prohaska N, Tavares JV, Marostica S, Kobayashi H, Ferreira ML, Campos KS, da Silva R, Brando PM, Dye DG, Huxman TE, Huete AR, Nelson BW, Saleska SR (2016) Leaf development and demography explain photosynthetic seasonality in Amazon evergreen forests. Science 351(6276):972-976, https://doi.org/10.1126/science.aad5068

Yang X, Post WM (2011) Phosphorus transformations as a function of pedogenesis: A synthesis of soil phosphorus data using Hedley fractionation method. Biogeosciences 8(10):2907-2916, https://doi.org/10.5194/bg-8-2907-2011

Zhu Z, Piao S, Myneni RB, Huang M, Zeng Z, Canadell JG, Ciais P, Sitch S, Friedlingstein P, Arneth A, Liu R, Mao J, Pan Y, Peng S, Peñuelas J, Poulter B (2016) Greening of the Earth and its drivers. Nat Clim Chang 6(August), https://doi.org/10.1038/NCLIMATE3004 
Figures

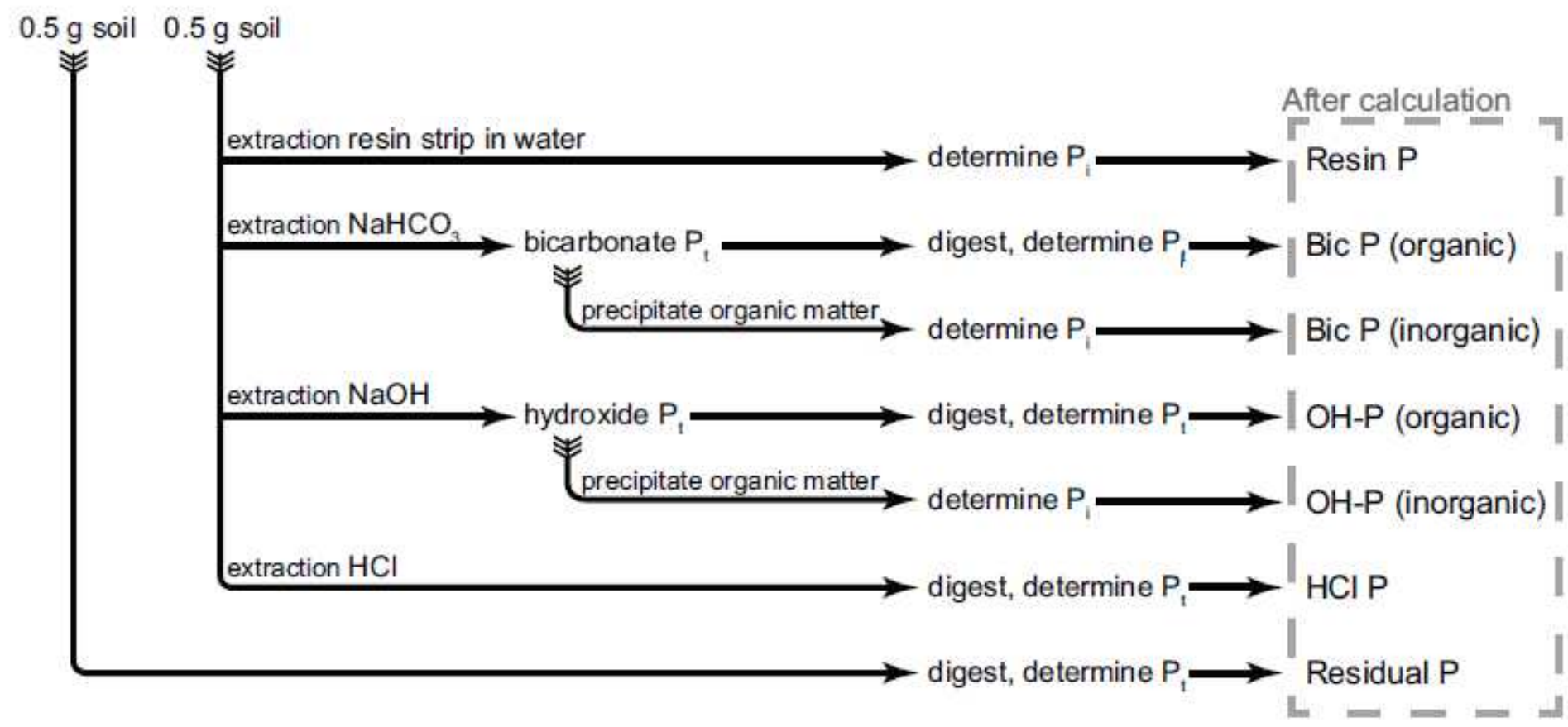

Figure 1

Schematic view of the Hedley fractionation method for sequential extraction of $\mathrm{P}$, modified from Tiessen and Moir (1993). The organic $\mathrm{P}(\mathrm{Po})$ is the difference between the inorganic $\mathrm{P}(\mathrm{Pi})$ and the total $\mathrm{P}(\mathrm{Pt})$. The residual fraction is the difference between the total $P$ from the entire sample and the sum of the extractable fractions. Details in Methods section 'Soil P-fractionation'.
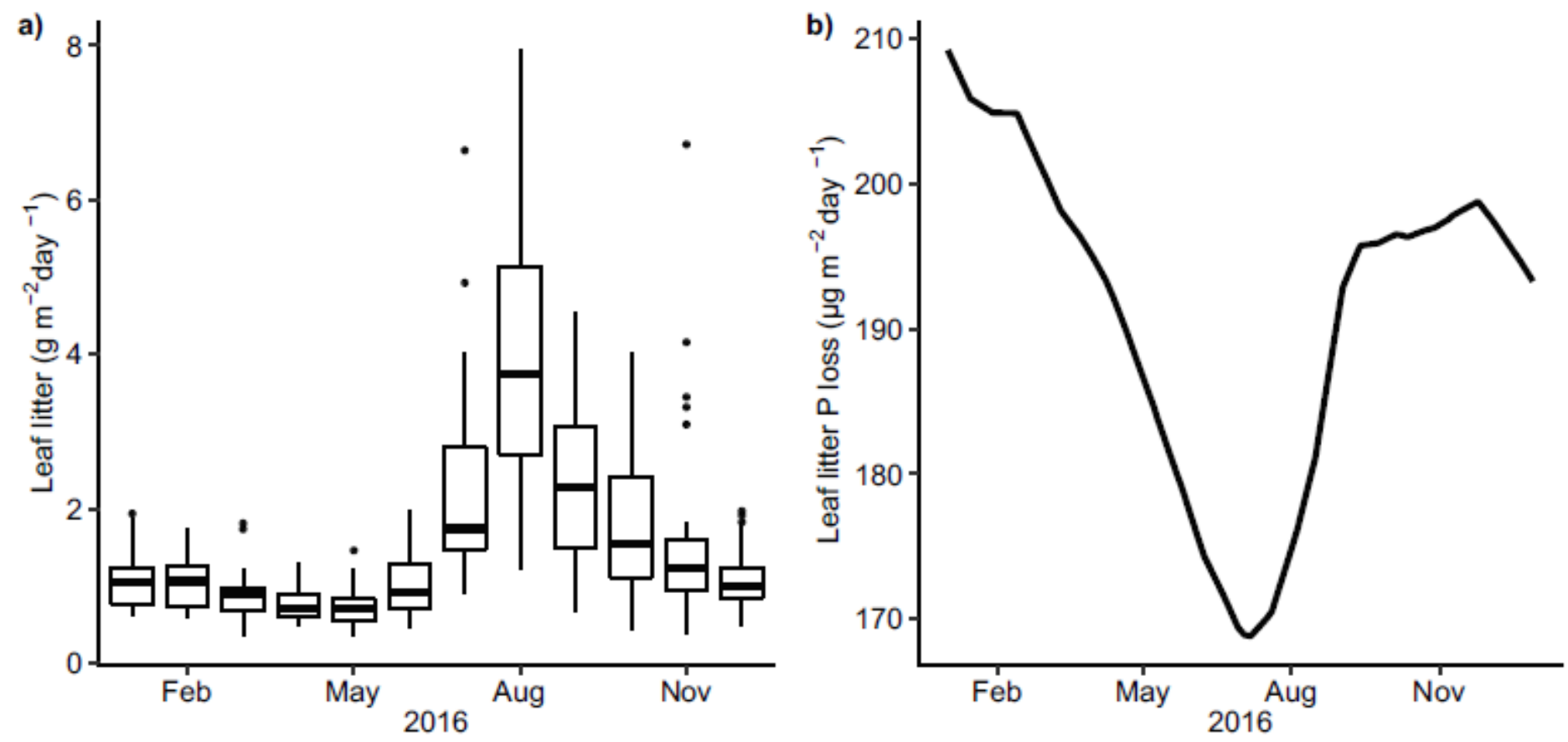

Figure 2 
a) Leaf litter collected at the AmazonFACE study site in 2016, and b) the modeled P-loss from that litter according to Eq. (3), used in this study as soil P-input from litter. Note that the litter data used to calculate this litter P loss is not entirely shown in a) (i.e. pre-2016 data was also used to get soil P-input). Details in Methods section 'Litterfall and P-input'.
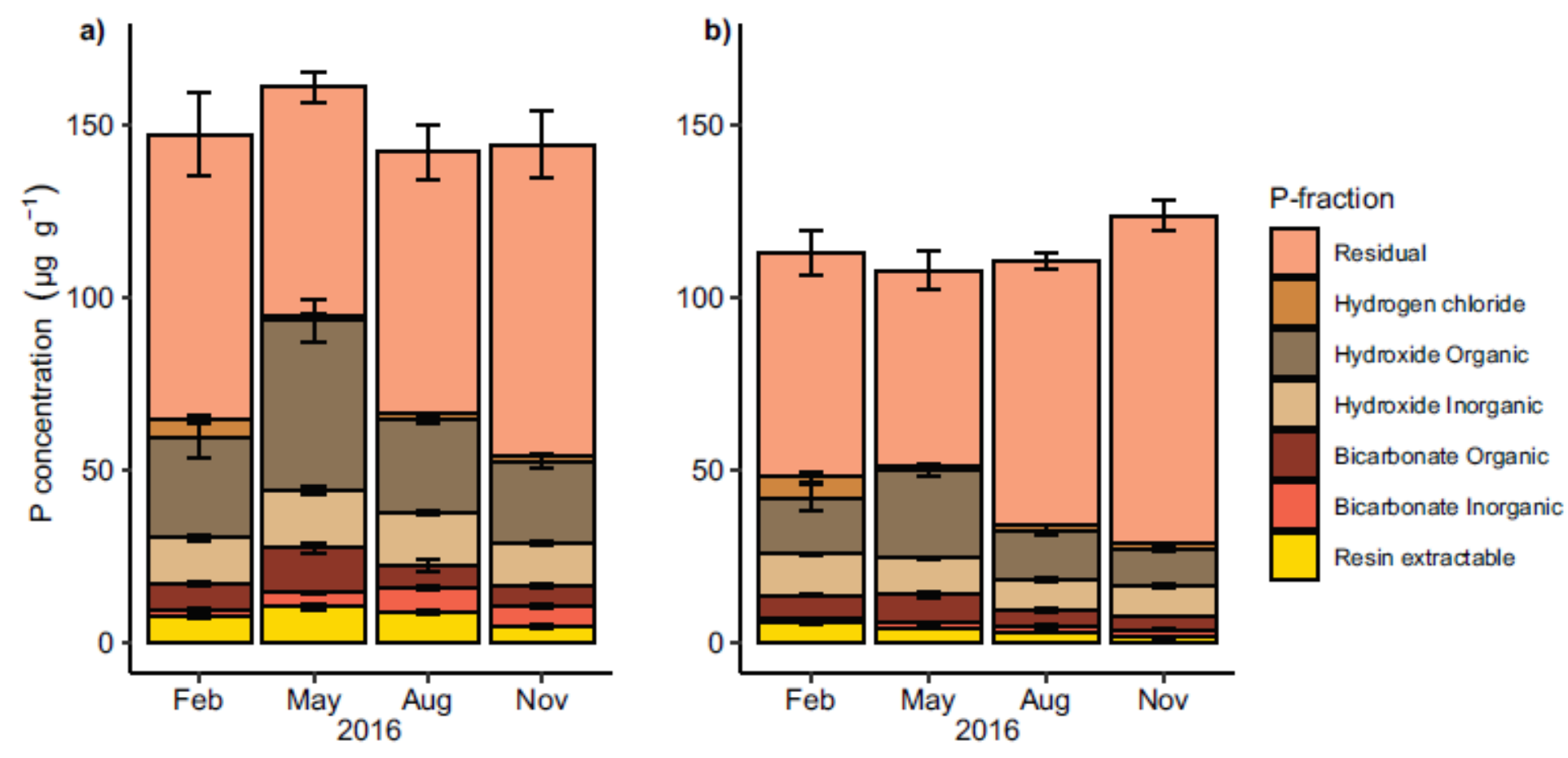

Figure 3

Cumulative Hedley soil P fractions determined in 4 campaigns at a) 0-5 cm depth, and b) at 5-15 cm soil depth. In their sequential extraction order (i.e. first extraction on the bottom, last extraction on top, cumulative bar so the top of the bar represents total $\mathrm{P}$ ). Concentration per dry soil, error bar represents standard error $(n=69)$. 

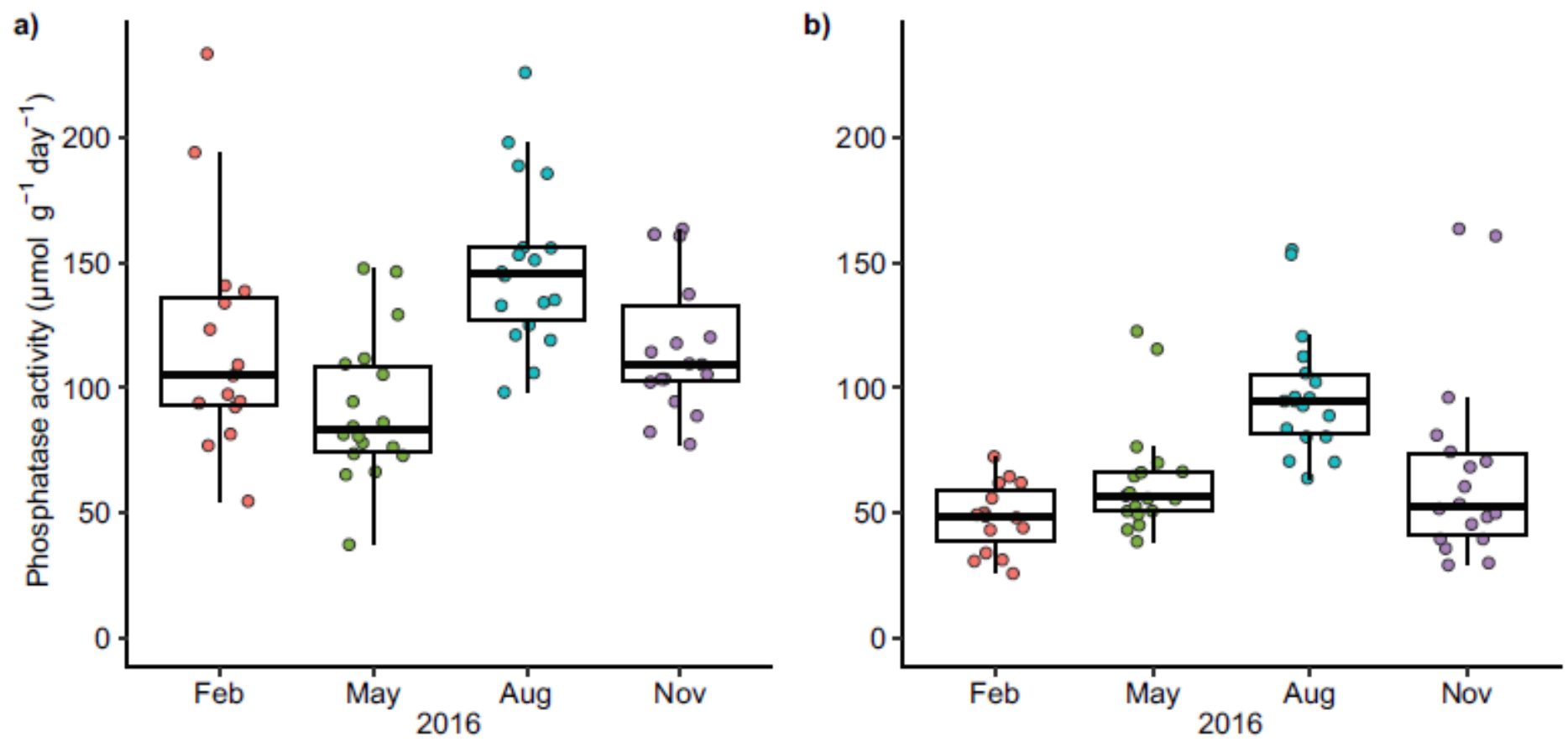

Figure 4

Potential activities of soil extracellular acid phosphatase at a) 0-5 cm depth, and b) at 5-15 cm depth. 

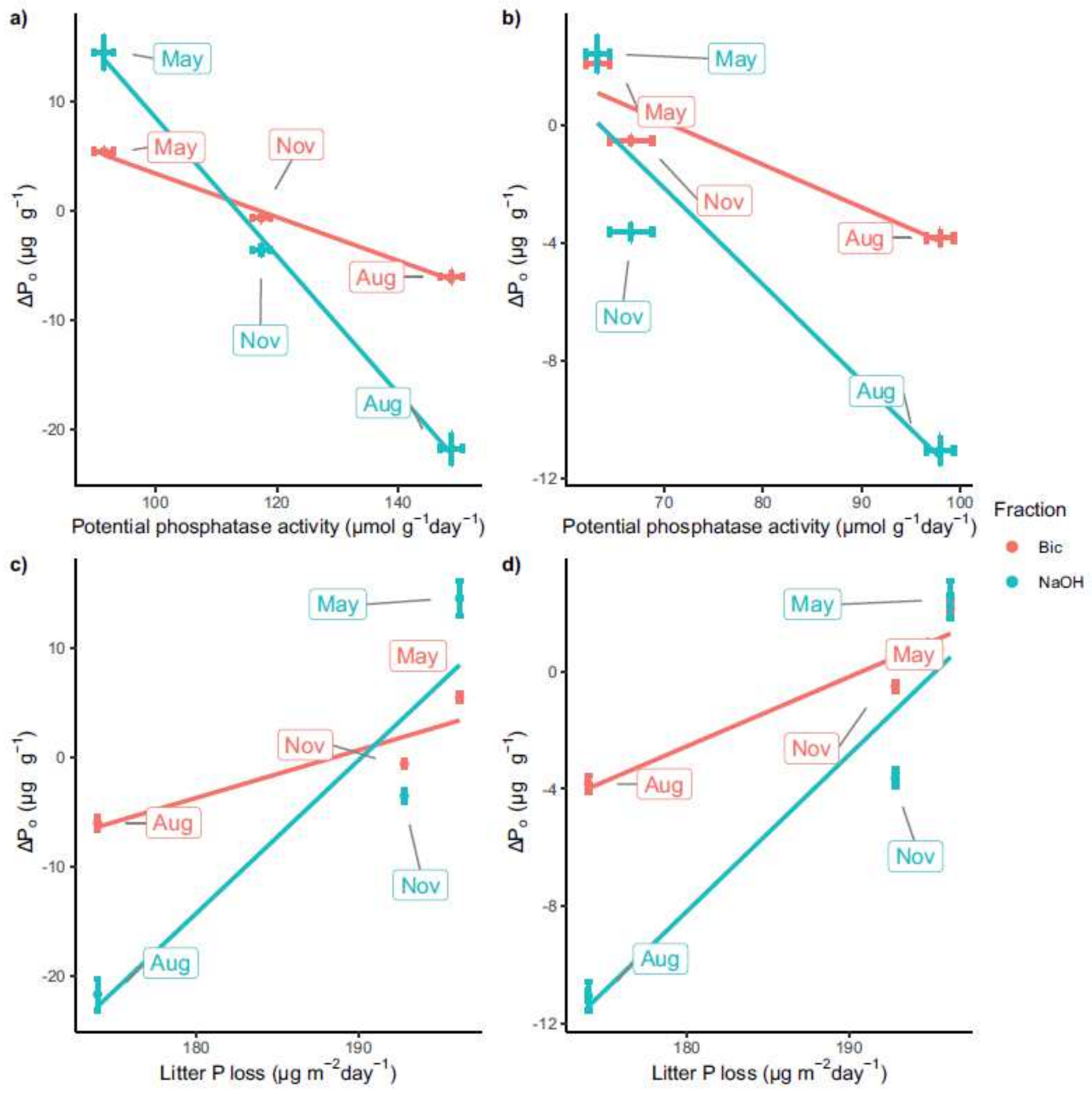

\section{Figure 5}

Relation between average changes in the organic fractions of soil $\mathrm{P}(\triangle \mathrm{Po})$, and assumed drivers of those changes. a) relation between average phosphatase and $\Delta \mathrm{Po}$ at 0-5 cm depth, ) at 5-15 cm depth, $\mathrm{c}$ ) the relation of modeled litter inputs (average between sampling dates, 2) with average $\Delta \mathrm{Po}$ at $0-5 \mathrm{~cm}$, and d) at the $5-15 \mathrm{~cm}$ depth. Error bars show the standard error. Litter inputs and phosphatase control seasonality of organic $P$ in a tropical soil 